\title{
Revisiting afro-alpine Lake Garba Guracha in the Bale Mountains of Ethiopia: rationale, chronology, geochemistry, and paleoenvironmental implications
}

\author{
L. Bittner (D) - M. Bliedtner • D. Grady • G. Gil-Romera • C. Martin-Jones • \\ B. Lemma • B. Mekonnen - H. F. Lamb - H. Yang • B. Glaser • \\ S. Szidat - G. Salazar - N. L. Rose $\cdot$ L. Opgenoorth $\cdot$ G. Miehe \\ W. Zech $\cdot$ M. Zech
}

Received: 25 October 2019/Accepted: 4 June 2020/Published online: 30 June 2020

(C) The Author(s) 2020

\begin{abstract}
Previous paleolimnological studies demonstrated that the sediments of Garba Guracha, situated at $3950 \mathrm{~m}$ asl in the afro-alpine zone of the Bale Mountains of Ethiopia, provide a complete Late Glacial and Holocene paleoclimate and environmental archive. We revisited Garba Guracha in order to retrieve new sediment cores and to apply new environmental proxies, e.g. charcoal, diatoms, biomarkers, and stable isotopes. Our chronology is established using ${ }^{210} \mathrm{~Pb}$ dating and radiocarbon dating
\end{abstract}

Electronic supplementary material The online version of this article (https://doi.org/10.1007/s10933-020-00138-w) contains supplementary material, which is available to authorized users.

L. Bittner $(\bowtie) \cdot$ B. Lemma · B. Mekonnen · B. Glaser Institute of Agronomy and Nutritional Sciences, Soil Biogeochemistry, Martin-Luther-Universität HalleWittenberg, Halle, Germany

e-mail: lucas.bittner@tu-dresden.de

B. Lemma

e-mail: bruklemma@gmail.com

B. Mekonnen

e-mail: betymekonnen19@gmail.com

B. Glaser

e-mail: bruno.glaser@landw.uni-halle.de

L. Bittner - M. Zech

Heisenberg Chair of Physical Geography with Focus on Paleoenvironmental Research, Institute of Geography, Technical University of Dresden, Dresden, Germany e-mail: michael_zech@gmx.de of bulk sedimentary organic matter, bulk $n$-alkanes, and charcoal. Although bedrock was not reached during coring, basal ages confirm that sedimentation started at the earliest $\sim 16 \mathrm{cal}$ kyr BP. The absence of a systematic age offset for the $n$-alkanes suggests that "pre-aging" is not a prominent issue in this lake, which is characterised by a very small afro-alpine catchment. X-ray fluorescence scans and total organic carbon contents show a prominent transition from minerogenic to organic-rich sediments around $11 \mathrm{cal}$ kyr BP coinciding with the Holocene onset. While an unambiguous terrestrial versus aquatic source identification seems challenging, the $n$-alkane-based $\mathrm{P}_{\text {aq }}$ proxy, TOC/N ratios, $\delta^{13} \mathrm{C}$ values, and the sugar

\footnotetext{
M. Bliedtner

Department of Physical Geography, Institute of

Geography, Friedrich-Schiller-University Jena, Jena,

Germany

e-mail: marcel.bliedtner@uni-jena.de

D. Grady · G. Gil-Romera · H. F. Lamb

Department of Geography and Earth Sciences,

Aberystwyth University, Aberystwyth, UK

e-mail:dig3@aber.ac.uk

G. Gil-Romera

e-mail: graciela.gil@ipe.csic.es

H. F. Lamb

e-mail: hfl@aber.ac.uk
} 
biomarker patterns suggest a predominantly autochthonous organic matter source. Supraregional climate events, such as the African Humid Period, the Younger Dryas (YD), a 6.5 cal kyr BP short drying event, and the $4.2 \mathrm{cal}$ kyr BP transition to overall drier climate are recorded in our archive. The Garba Guracha record suggests that northern hemisphere forcings played a role in the Eastern African highland paleoclimate.

Keywords Paleolimnology · Afro-alpine · Radiocarbon dating $\cdot$ XRF scanning $\cdot$ Sedimentation rate $\cdot$ Biomarkers

\section{Introduction}

Eastern Africa, and Ethiopia in particular, has received much attention from archeologists and paleoclimatologists (Viehberg et al. 2018; Lamb et al. 2018). This may be attributed to Quaternary climatic changes being widely acknowledged to have played a role in the early history of modern humans in Africa. Climatic extremes may have caused human populations to take refuge in the Ethiopian highlands (Brandt et al. 2012), including the Bale Mountains (Fig. 1). Ossendorf et al. (2019) recently highlighted that Middle Stone Age

\section{G. Gil-Romera}

Department of Geo-Environmental Processes and Global Change, CSIC, Pyrenean Institute of Ecology, Zaragoza, Spain

C. Martin-Jones

Department of Geography, University of Cambridge, Cambridge CB2 3EN, UK

e-mail: cmm201@cam.ac.uk

C. Martin-Jones

Limnology Unit, Department of Biology, Ghent

University, 9000 Gent, Belgium

\section{B. Mekonnen · W. Zech}

Institute of Soil Science and Soil Geography, University of Bayreuth, 95440 Bayreuth, Germany

e-mail: w.zech@uni-bayreuth.de

H. Yang · N. L. Rose

Environmental Change Research Centre, University

College London, Gower Street, London WC1E 6BT, UK

e-mail: handong.yang@ucl.ac.uk foragers occupied a rock shelter at $3469 \mathrm{~m}$ asl from 47 to $31 \mathrm{kyr} \mathrm{BP}$, during times of the largest extent of the glaciation in the Bale Mountains.

Earlier studies of the Quaternary climate and environmental history of the Bale Mountains include Osmaston et al. (2005) on glacial geology, Kuzmicheva et al. (2017) on pollen and hyrax deposits and Gil-Romera et al. (2019) on pollen and charcoal. Umer et al. (2007) and Tiercelin et al. (2008) studied the sedimentary record of Garba Guracha, using sedimentological, geochemical and pollen analyses, showing that Garba Guracha is one of the longest, most continuous high-resolution Late Quaternary environmental archives from highland Africa.

Recently, the importance of compound-specific ${ }^{14} \mathrm{C}$ dating in lake sediments has been shown by Douglas et al. (2014) and Gierga et al. (2016). The occurrence or nonoccurrence of age differences between organic matter components provides valuable information for the catchment itself and for the interpretation of proxies, especially in a multi-proxy approach.

The rationale for revisiting Garba Guracha was (1) to make this archive accessible by retrieving new sediment cores, (2) to examine age offsets in the organic matter components by applying bulk $n$-alkane dating and (3) to apply charcoal, diatom, biomarker and stable isotope analyses, not made in previous

\author{
N. L. Rose \\ e-mail: n.rose@ucl.ac.uk \\ S. Szidat · G. Salazar \\ Department of Chemistry and Biochemistry and Oeschger \\ Centre for Climate Change Research, University of Bern, \\ Bern, Switzerland \\ e-mail: soenke.szidat@dcb.unibe.ch \\ G. Salazar \\ e-mail: gary.salazar@dcb.unibe.ch \\ L. Opgenoorth · G. Miehe \\ Department of Geography, University of Marburg, \\ Marburg, Germany \\ e-mail: Lars.Opgenoorth@staff.uni-marburg.de \\ G. Miehe \\ e-mail: miehe@staff.uni-marburg.de
}


studies of the Garba Guracha cores. Together with non-pollen palynomorph and renewed pollen analyses, these new analyses provide proxy records of paleofire, limnology, vegetation, climate, and human environments. In this paper, we describe the sedimentary sequence and evaluate the organic matter origin of the new (2017) cores, establish a robust chronology with the first tephra correlations and present the first biogeochemical and biomarker results.

\section{Study site}

Garba Guracha is located in the Bale Mountains of the Bale-Arsi Massif, situated east of the Main Ethiopian Rift (Fig. 1). The highest plateau of the Bale Mountains is the Sanetti Plateau at an altitude between 3800 to $\sim 4200 \mathrm{~m}$ asl and an area of $600 \mathrm{~km}^{2}$ bordered by a steep escarpment to the south (Osmaston et al. 2005). The north and northeast are characterized by valley structures deeply incised by northward descending rivers. The volcanic plateau overlies older volcanic material and was formed by solidified horizontal lava consisting of alkali basalt, trachyte, and tuffs with rhyolites (Uhlig and Uhlig 1991; Williams 2016). The plateau and the valleys were locally glaciated during the Last Glacial Maximum (LGM) (Osmaston et al. 2005; Ossendorf et al. 2019). The glacial cirque Garba Guracha (6.875781 N, 39.878075 E) was first described by Werdecker (1962) and has also been described in detail by Umer et al. (2007) and Tiercelin et al. (2008).
It is located at $3950 \mathrm{~m}$ asl, extends to about $500 \times 300 \mathrm{~m}$ in size, has a maximum water depth of $6 \mathrm{~m}$ and a very small watershed $\left(0.15 \mathrm{~km}^{2}\right)$. The bedrock of the Garba Guracha catchment consists mainly of basaltic lavas. The cirque base is formed by trachytic tuff, which outcrops only on the southern and southeastern slopes (Tiercelin et al. 2008). The catchment bedrock is carbonate-poor (Löffler 1978; Uhlig and Uhlig 1991). The northeast-facing cirque lies between the Ericaceous and afro-alpine vegetation belts which are continuous on the northeastern side into the Togona Valley. The lake has an outlet during the rainy season. A marshy alluvial plain fed by several springs extends to the south of the lake.

The climate of the Bale Mountains varies from north to south due to differences in altitude, aspect and continental hot air masses (Uhlig and Uhlig 1991; Kidane et al. 2012).

The mean annual temperature at Dinsho (7.105016 ${ }^{\circ} \mathrm{N} 39.776001^{\circ} \mathrm{E}, 3207 \mathrm{~m}$ asl, $25 \mathrm{~km} \mathrm{NNW}$ of Garba Guracha) is $11.8^{\circ} \mathrm{C}$, and the mean minimum temperature for the coldest month is $0.6^{\circ} \mathrm{C}$ (Hillman 1986). Ten newly installed climate stations across the Bale Mountains have provided modern climate data since 2017. The results from 2017 show a mean annual temperature of $4.9^{\circ} \mathrm{C}$ at the Angesso Station $\left(6.8964^{\circ} \mathrm{N}, 39.9085^{\circ} \mathrm{E}, 3949 \mathrm{~m}\right.$ asl $)$ which is located $4 \mathrm{~km}$ northeast of Garba Guracha.

Uhlig (1988) and Miehe and Miehe (1994) state that two moisture sources, the Indian Ocean monsoon and the equatorial westerlies, bring precipitation to the

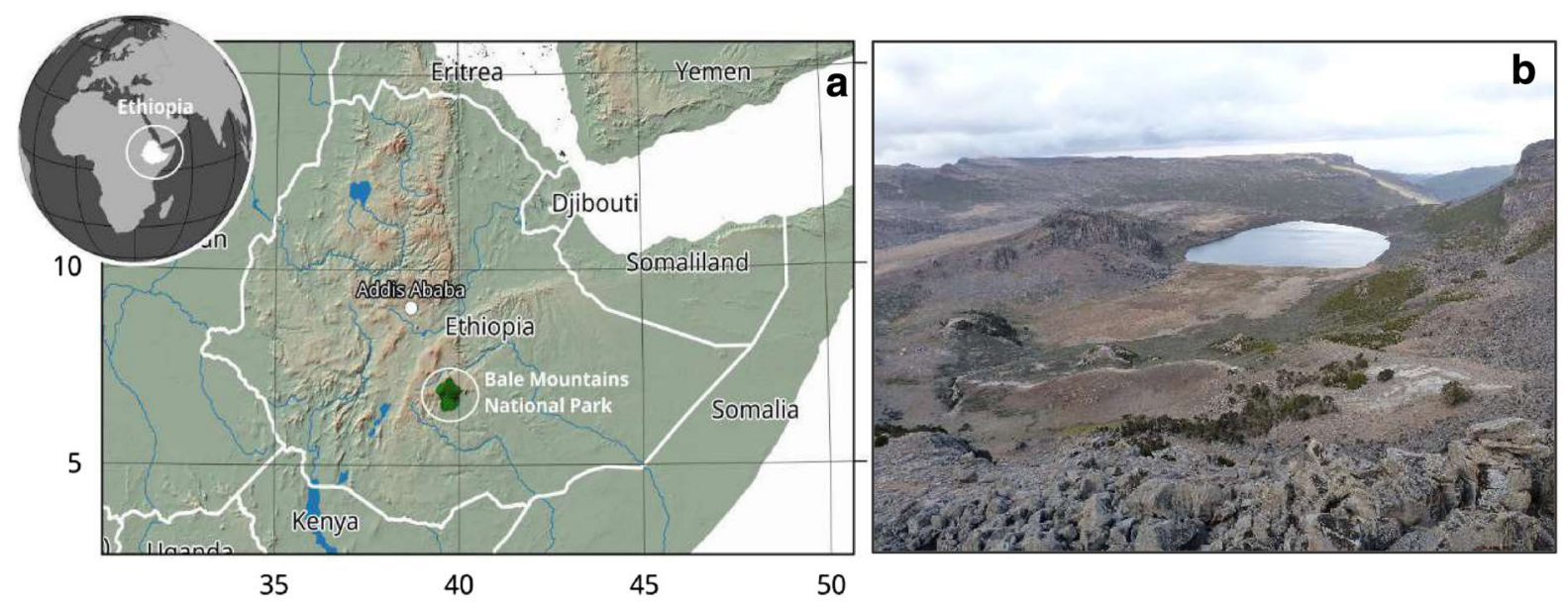

Fig. 1 a Map of the study area (Bale Mountains National Park) situated east of the Ethiopian Rift Valley in Ethiopia, Eastern Africa (made by Dr. Miguel Sevilla-Callejo); b Garba Guracha catchment and glacial cirque 
Bale Mountains. High seasonality characterizes the rainfall pattern with a dry season from November to February and a bimodal wet season from March to October. Precipitation maxima occur in April/May and September/October, respectively (Woldu et al. 1989). The highest monthly rainfall, related to the convergence of southwest and northeast air masses, occurs in the months of July to September. Mean annual precipitation increases with altitude from $925 \mathrm{~mm}$ at Goba (elevation $2720 \mathrm{~m}$ ) to Chorchora with $1086 \mathrm{~mm}$ at $3500 \mathrm{~m}$ asl. At higher elevations, the mean annual precipitation decreases again $(852 \mathrm{~mm}$ at Konteh, $4050 \mathrm{~m}$ ) (Umer et al. 2007). Recently installed climate stations support this finding with annual precipitation in the year 2017 decreasing from $1097 \mathrm{~mm}$ at Angesso Station (elevation $3949 \mathrm{~m}$ ) to $711 \mathrm{~mm}$ at the EWCP Station (elevation $4124 \mathrm{~m}$ ) and even further to $468 \mathrm{~mm}$ at Tulu Dimtu (elevation $4385 \mathrm{~m}$ ) (2017, unpublished data). The afro-alpine regions, including the Sanetti Plateau, are characterized by strong diurnal temperature differences between day and night. Hillman (1988) reported on a diurnal temperature range of $40^{\circ} \mathrm{C}\left(-15^{\circ} \mathrm{C}\right.$ to $\left.+26^{\circ} \mathrm{C}\right)$.

\section{Material and methods}

In February 2017, we retrieved two overlapping sediment cores using a Livingstone piston corer from a raft anchored at $4.8 \mathrm{~m}$ water depth. The replicate cores (BAL-GGU17-1A and BAL-GGU17-1B) were taken in sequential 1-m sections, with core $1 \mathrm{~B}$ sections taken to overlap those of core $1 \mathrm{~A}$ by $70 \mathrm{~cm}$. Sediments at and below the water-sediment interface [Section BAL-GGU17-1A-1L (65 cm)] were sub-sampled at $1 \mathrm{~cm}$ intervals in the field. A maximum sediment depth of $1550 \mathrm{~cm}$ was reached, similar to the depth $(1582 \mathrm{~cm})$ achieved by Tiercelin et al. (2008). Unfortunately, that core was not available for further analyses. The bottom four sections of each of our cores were difficult to retrieve and extrude due to densely compacted sediments, coarse sand, and gravel. Bedrock or glacial diamicts were not reached. In the laboratory, the cores were split, described and stored at $4{ }^{\circ} \mathrm{C}$. Sampling for chronological controls and proxy analyses was carried out on core BALGGU17-1B as its extrusion was more complete than core BAL-GGU17-1A.
Chronology and dating

\section{Radiocarbon dating}

For radiocarbon dating, we took a total of 31 samples, comprising 18 bulk sediment samples, 8 bulk $n$-alkane and 5 charcoal samples from the top $9 \mathrm{~m}$ of the BALGGU17-1B core (ESM1). Bulk $n$-Alkane and bulk sediment samples were taken at the same depths to test for age offsets.

Bulk sediment and charcoal samples were weighed into glass centrifuge vials and treated with $1 \mathrm{~N} \mathrm{HCl}$ for $8 \mathrm{~h}$ at $60{ }^{\circ} \mathrm{C}$ to remove carbonates from the samples. They were subsequently washed and rinsed with ultrapure water to $\mathrm{pH}$ neutrality. Samples were then packed in tin boats (Elementar, $6 \times 6 \times 12$ ) for ${ }^{14} \mathrm{C}$ measurements.

For bulk $n$-alkane dating the total lipid extract (TLE) was obtained by constant rinsing with solvent (dichloromethane: methanol in a ratio of 9:1) using a soxhlet system. After rotary evaporation, the TLE was dissolved again with $n$-hexane and transferred onto aminopropyl pipette columns (Supelco, $45 \mathrm{um}$ ). The different fractions of the TLE (nonpolar fraction, including $n$-alkanes; polar fraction, including alcohols; acids) were selectively eluted from the columns using three solvents of increasing polarity ( $n$-hexane; dichloromethane:methanol $1: 1$; diethyl ether:acetic acid 19:1). The $n$-alkane fraction was then loaded onto $\mathrm{AgNO}_{3}$-coated silica and zeolite pipette columns (Geokleen 5A, GHGeochemical Services) for further purification. The zeolite with the trapped $n$-alkanes was dried in an oven $\left(12 \mathrm{~h}, 40^{\circ} \mathrm{C}\right)$. After dissolving the zeolite in hydrofluoric acid, the $n$-alkanes were recovered using liquid-liquid extraction with $n$-hexane. Prior to ${ }^{14} \mathrm{C}$-measurements, the $n$-alkanes were transferred with dichloromethane (DCM) into tin capsules (Elementar, Art. Nr. 05001727, $3.5 \times 5.5 \times 0.1 \mathrm{~mm}$ ) and the DCM was subsequently evaporated using a heating plate at $40{ }^{\circ} \mathrm{C}$.

${ }^{14} \mathrm{C}$ measurements were performed at the MIni CArbon DAting System (MICADAS) AMS coupled online to an elemental analyzer (Vario MICRO cube from Elementar) at the LARA AMS Laboratory, University of Bern (Szidat et al. 2014). Results were reported as fraction modern $\left(\mathrm{F}^{14} \mathrm{C}\right)$, which is the activity ratio of a sample normalized to the modern reference material Oxalic Acid II (National Institute of Standards and Technology). $\quad \mathrm{F}^{14} \mathrm{C}$ results were 
corrected for cross and constant contamination following the contamination drift model of Salazar et al. (2015). Constant contamination for the bulk $n$-alkanes was obtained from 10 combined tin capsules that yielded $0.94 \mu \mathrm{g}$ carbon for a single cap with $\mathrm{F}^{14} \mathrm{C}$ values of 0.8145 . Constant contamination for the bulk sediment and charcoal samples was obtained from 10 combined tin boats that yield $1.41 \mu \mathrm{g}$ carbon for a single boat with $\mathrm{F}^{14} \mathrm{C}$ values of $0.7390 .{ }^{14} \mathrm{C}$ ages were calibrated to cal yr BP with the IntCal13 calibration curve (Reimer et al. 2013).

\section{Radiometric dating}

The dried sediment samples of the surface core BALGGU17-1A-1L were analyzed for ${ }^{210} \mathrm{~Pb},{ }^{226} \mathrm{Ra},{ }^{137} \mathrm{Cs}$, and ${ }^{241} \mathrm{Am}$ by direct gamma assay in the Environmental Radiometric Facility at University College London using an ORTEC HPGe GWL series well-type coaxial low background intrinsic germanium detector. Lead-210 was determined via its gamma emissions at $46.5 \mathrm{keV}$ and ${ }^{226} \mathrm{Ra}$ by the $295 \mathrm{keV}$ and $352 \mathrm{keV}$ gamma rays emitted by its daughter isotope ${ }^{214} \mathrm{~Pb}$ following 3 weeks storage in sealed containers to allow radioactive equilibration. Cesium-137 and ${ }^{241} \mathrm{Am}$ were measured by their emissions at $662 \mathrm{keV}$ and $59.5 \mathrm{keV}$ (Appleby et al. 1986). The absolute efficiencies of the detector were determined using calibrated sources and sediment samples of known activity. Corrections were made for the effect of selfabsorption of low energy gamma rays within the sample (Appleby et al. 1992).

Lead-210 dates were calculated using the CRS (constant rate of ${ }^{210} \mathrm{~Pb}$ supply) dating model (Appleby 2001). The CRS dating model places 1963 depth at $14.5 \mathrm{~cm}$, which is considerably deeper than the depth suggested by the ${ }^{137} \mathrm{Cs}$ and ${ }^{241} \mathrm{Am}$ records. The corrected CRS chronologies and sediment accumulation rates were calculated by using the sediments at $7.5 \mathrm{~cm}$ as formed in 1963 (ESM1).

\section{Spheroidal carbonaceous particle (SCP) analysis}

Spheroidal carbonaceous particles (SCPs) are a component of fly-ash produced only from the high temperature industrial combustion of coal-series and oil fuels. SCP concentration profiles provide an additional means to provide independent dates at the regional scale while the rapid increase in SCP accumulation in the 1950s appears to be a global signal (Rose 2015). SCP analysis involved sequential removal of unwanted sediment fractions using nitric, hydrofluoric and hydrochloric acids resulting in a final suspension in water (Rose 1994). A known fraction of this suspension was then evaporated onto a coverslip, mounted onto a glass slide, and the SCPs enumerated under a light microscope at $400 \times$ magnification. Standard criteria for SCP identification were followed (Rose 2008). Analytical blanks and SCP reference material (Rose 2008) were included with all sample digestions. The detection limit for the technique is typically less than $100 \mathrm{~g} \mathrm{DM}^{-1}$ and calculated concentrations generally have an accuracy of approximately $\pm 45 \mathrm{~g} \mathrm{DM}^{-1}$.

\section{Tephra analysis}

Three tephra layers (GGT-1, GGT-2, and GGT-3) were identified in the Garba Guracha sediments. These were geochemically fingerprinted to test whether they could be matched to the tephra layers that MartinJones et al. (2017) observed and dated in sediment cores from the Main Ethiopian Rift lakes, Tilo, Awassa, and Chamo. The oldest tephra layer GGT-3 has yet to be analyzed but may provide a further tie point to regional lakes in the future.

Samples were collected from across the entire thickness of the tephra and, in order to isolate glass shards for geochemical analysis, the samples were wet sieved to $>25 \mu \mathrm{m}$ and separated using a solution of sodium polytungstate to a density of $>1.95 \mathrm{~g} \mathrm{~cm}^{-3}$. Shards from each tephra were mounted in an epoxy resin block which was ground and polished to reveal the interior of the glass for analysis. First, the shards were analyzed for major element concentrations using a Cameca SX-100 WDS electron microprobe (EPMA) at the Department of Earth Sciences, University of Cambridge. The analysis was set up to minimize alkali element migration through using a $10 \mu \mathrm{m}$ defocused beam set at $6 \mathrm{nA}$ and $15 \mathrm{kV}$ and counting $\mathrm{Na}$ for $10 \mathrm{~s}$, $\mathrm{Cl}$ and $\mathrm{P}$ for $60 \mathrm{~s}$ and all other elements for $30 \mathrm{~s}$. A series of mineral standards were used to calibrate the instrument and concentrations were quantified using the PAP absorption correction method. Data presented in the text and figures have been normalized to $100 \%$ to account for variable secondary hydration of the glass; for the unprocessed data see ESM1. 
Second, the glass shards were analyzed for their trace element concentrations using a Thermo Scientific iCapQ coupled to a Teledyne G2 Excimer laser (LA-ICP-MS) in the iCRAG laboratory, Trinity College Dublin. The shards were analyzed with $40 \mu \mathrm{m}^{2}$ laser spots, with the laser firing at $5 \mathrm{~Hz}$ and counting for $40 \mathrm{~s}$ on both the sample and the blank. Counts were calibrated against assays of NIST612 with the average

${ }^{29} \mathrm{Si}$ concentration for each tephra layer (obtained via EPMA) used as an internal standard. Data were reduced using Iolite 3.4, using Ca correction as advocated by Tomlinson et al. (2010).

For each analytical session with the EPMA and the LA-ICP-MS, the MPI-DING basaltic, andesitic and rhyolitic natural glass standards (Jochum et al. 2006) were analyzed in order to monitor instrument accuracy.

\section{Age-depth model}

For establishing an age-depth model, we used the Bayesian approach implemented in the package Bacon v 2.2 (Blaauw and Christen 2011) available for $\mathrm{R}$ (CRAN 2017). Bacon calibrates all ${ }^{14} \mathrm{C}$ dates simultaneously according to the stratigraphic principle (Blaauw et al. 2007) applying the IntCal13 calibration curve (Reimer et al. 2013). This Bayesian method defines accumulation rates using a gamma autoregressive semi-parametric model with several subdivisions along the sediment that can be set up as a prior to the model (parameter $\alpha$ and thick respectively). This serves as a smoothness factor for the aging series, followed by a self-adjusting Markov Chain Monte Carlo (MCMC) building a robust-to-outliers age model (Blaauw and Christen 2011). The Bayesian approach aims to build a realistic age-depth relationship that often implies no linear deposition.

\section{XRF scanning}

XRF analysis for both cores was performed at Aberystwyth University using the Itrax ${ }^{\mathrm{TM}}$ core scanner. Standard scanning procedure for an Itrax scanner was undertaken (Itrax scanner specifications and procedures outlined in (Croudace et al. 2006)). Scan settings were $30 \mathrm{kV}, 45 \mathrm{~mA}$ using a step size of $500 \mu \mathrm{m}$ for the Garba Guracha cores. XRF and X-ray exposure times were set to $15 \mathrm{~s}$ and $200 \mathrm{~ms}$, respectively, for both cores. Fine-tuning of the detector parameters was performed before each scan to match the actual and fitted spectra and minimize the mean square error (MSE) value. As a result, MSE values were maintained below 2 (mean $=1.59 \pm 0.3$ ). Following the calibration of scanner settings, a layer of $1.5 \mu \mathrm{m}$ thick film was used to cover the core to minimize moisture loss during scanning.

Significant changes in water and organic content may lead to inaccurate detection of some elements, resulting in downcore changes in raw element profiles unrelated to sediment geochemistry (Löwemark et al. 2011). Consequently, to minimize the effects of sediment-water and organic content, normalization of raw element data by the total scatter (both the incoherent and coherent data, equivalent to Compton and Rayleigh scattering, respectively) is commonly used (Kylander et al. 2011). Normalization of the peak area data was achieved using the total scatter.

Due to low and noisy signals, only $\mathrm{K}, \mathrm{Ca}, \mathrm{Ti}, \mathrm{Fe}$, and $\mathrm{Rb}$ could be evaluated robustly and were further considered for interpretation. The surface core (BALGGU17-1A-1L), as well as two core sections of BALGGU17-AB and 1B from 1245 to $1485 \mathrm{~cm}$ sediment depth, were not scanned because of high water content and coarse and gravel material, respectively. Therefore, the results presented in this study are missing the top $20 \mathrm{~cm}$ and $240 \mathrm{~cm}$ near the core base.

Biogeochemical analyses

Total carbon (TC), total nitrogen $(\mathrm{N})$ and stable carbon and nitrogen isotopic composition $\left(\delta^{13} \mathrm{C}\right.$ and $\delta^{15} \mathrm{~N}$, respectively) were determined for 110 mixed sediment samples covering roughly $10 \mathrm{~cm}$ intervals. The analyses were carried out on dried and ground samples at the Institute of Agronomy and Nutritional Sciences, Soil Biogeochemistry, Martin-Luther-University Halle-Wittenberg using an EuroVector EA 3000 elemental analyzer (Hekatech, Wegberg, Germany) coupled via a Conflow III Interface to a Delta V Advantage isotope ratio mass spectrometer (IRMS; both from Thermo Fisher Scientific, Bremen, Germany). The results were calibrated using standard materials with known total carbon, nitrogen, ${ }^{13} \mathrm{C}$ and ${ }^{15} \mathrm{~N}$ contents (IAEA $\mathrm{N}_{2}$, IAEA $\mathrm{CH}_{6}$, IAEA $\mathrm{NO}_{3}$, IAEA $\mathrm{CH}_{7}$, IAEA 305A, USGS 41). Following the international standard regulations (Coplen $2011 ;{ }^{13} \mathrm{C}$ : Vienna Pee Dee Belemnite, VPDB; ${ }^{15} \mathrm{~N}$ : atmospheric $\mathrm{N}_{2}$, Air) all isotope results are reported in the common 
$\delta$-notation. Concerning total carbon please note that (1) the bedrock in the catchment is reported to be carbonate-poor/free and (2) we performed Scheibler analyses (Allison 1960) on several sediment test samples that yielded $0 \%$ inorganic carbon content. Given that moreover, our TC record is in excellent agreement with the TOC record of Tiercelin et al. (2008), we use the term TOC instead of TC from here on for our record.

\section{$n$-Alkane and sugar quantification}

The $n$-alkanes from the extracted TLEs were quantified using a GC-2010 series gas chromatograph coupled with a flame ionization detector (GC-FID; Shimadzu, Kyoto, Japan). For linear calibration a C8C40 saturated $n$-alkane standard mixture (Supelco 49452-U) was repeatedly analyzed in each batch at different concentrations $\left(10 \mu \mathrm{g} \mathrm{ml}^{-1}, 50 \mu \mathrm{g} \mathrm{ml}^{-1}\right.$ and $100 \mu \mathrm{g} \mathrm{ml}^{-1}$ ). All work was carried out at the Institute of Agronomy and Nutritional Sciences, Soil Biogeochemistry, Martin-Luther-University, HalleWittenberg.

Sugar biomarkers were extracted following the method described by Zech and Glaser (2009). Briefly, the monosaccharides were hydrolytically extracted from the homogenized samples using $4 \mathrm{M}$ trifluoroacetic acid at $105{ }^{\circ} \mathrm{C}$ for $4 \mathrm{~h}$ (Amelung et al. 1996). The monosaccharides were then filtered over glass fiber filters, evaporated and further purified over XAD7 and DOWEX 50WX8 columns. After freeze-drying, the samples were derivatized (methyloximetrimethylsilyl-derivatisation). The derivatization follows the method of Andrews (1989) to enable a quantification of a large range of sugars (arabinose (ara), fucose (fuc), galactose, glucose, mannose, rhamnose, ribose and xylose (xyl)). The quantification of these sugars was also carried out on a GC-FID (Shimadzu, Kyoto, Japan). Note that for this study only the sugar results for ara, fuc, and xyl are evaluated.

\section{Results}

The sedimentary sequence-Master core and lithofacies

A master core of the overlapping BAL-GGU17-1A and $1 \mathrm{~B}$ cores (Fig. 2) was created by visual correlation of several XRF elements like $\mathrm{Ti}, \mathrm{Fe}, \mathrm{Rb}$, and $\mathrm{K}$ using Stratfit (Sagnotti and Caricchi 2018). Stratfit combines all core sections into one depth model. Additionally, the core sections were checked for contaminated parts, especially at the top and the bottom of individual core sections. The master core consists mainly of sections of the BAL-GGU17-1B core due to less contamination or disturbance than in core $1 \mathrm{~A}$. Only in the lower part of the sequence, a few 1A core sections were used instead of 1B core sections (Fig. 2).

The sedimentary sequence of core GGU17 consists of green banded siliciclastic fine material interbedded with layers of coarser material and gravel in the lower part (Fig. 2). It can be divided into 4 lithostratigraphic units:

Unit $1(1552-1476 \mathrm{~cm})$ contains greenish banded siliciclastic coarse sand.

Unit $2(1476-1276 \mathrm{~cm})$ is comprised of two meters of highly coarse silt and gravel.

Unit $3(1276-1476 \mathrm{~cm})$ consists mostly of green banded siliciclastic material mostly coarse silt with amorphous organic matter (OM) intersected with one layer of fine silt between 1219-1166 cm and a layer of coarse sand at $1031-966 \mathrm{~cm}$. The diatom content of this unit is about $10 \%$.

Unit $4(838-70 \mathrm{~cm})$ consists of nearly $8 \mathrm{~m}$ of dark brown massive organic mud with varying diatom content. This unit is intersected by a small layer of green-greyish massive siliciclastic fine silt at $828 \mathrm{~cm}$ and two layers of organic poor, finer sediments at $496 \mathrm{~cm}$ and $505 \mathrm{~cm}$.

Three tephra layers have been identified at $129 \mathrm{~cm}$, $604 \mathrm{~cm}$, and $1198 \mathrm{~cm}$ depth, respectively. A fourth tephra layer mentioned by Tiercelin et al. (2008) $(\sim 340 \mathrm{~cm})$ was not detected.

\section{Chronology}

\section{Tephra age}

Two grey tephra layers were analysed as part of this study. They occur at $129 \mathrm{~cm}$ and $604 \mathrm{~cm}$ depth in the Garba Gurache core (Fig. 2), are no more than $1 \mathrm{~cm}$ in thickness and contain clear, bubble wall and pumiceous glass shards. According to the Garba Gurache age model, tephra GGT-1 has a modeled age of 1.2-1.6 cal kyr BP and GGT-2 has an age of 7.8-8.1 cal kyr BP. Glass shards in both tephra layers have a similar rhyolitic composition (ESM1), however, GGT-1 can 

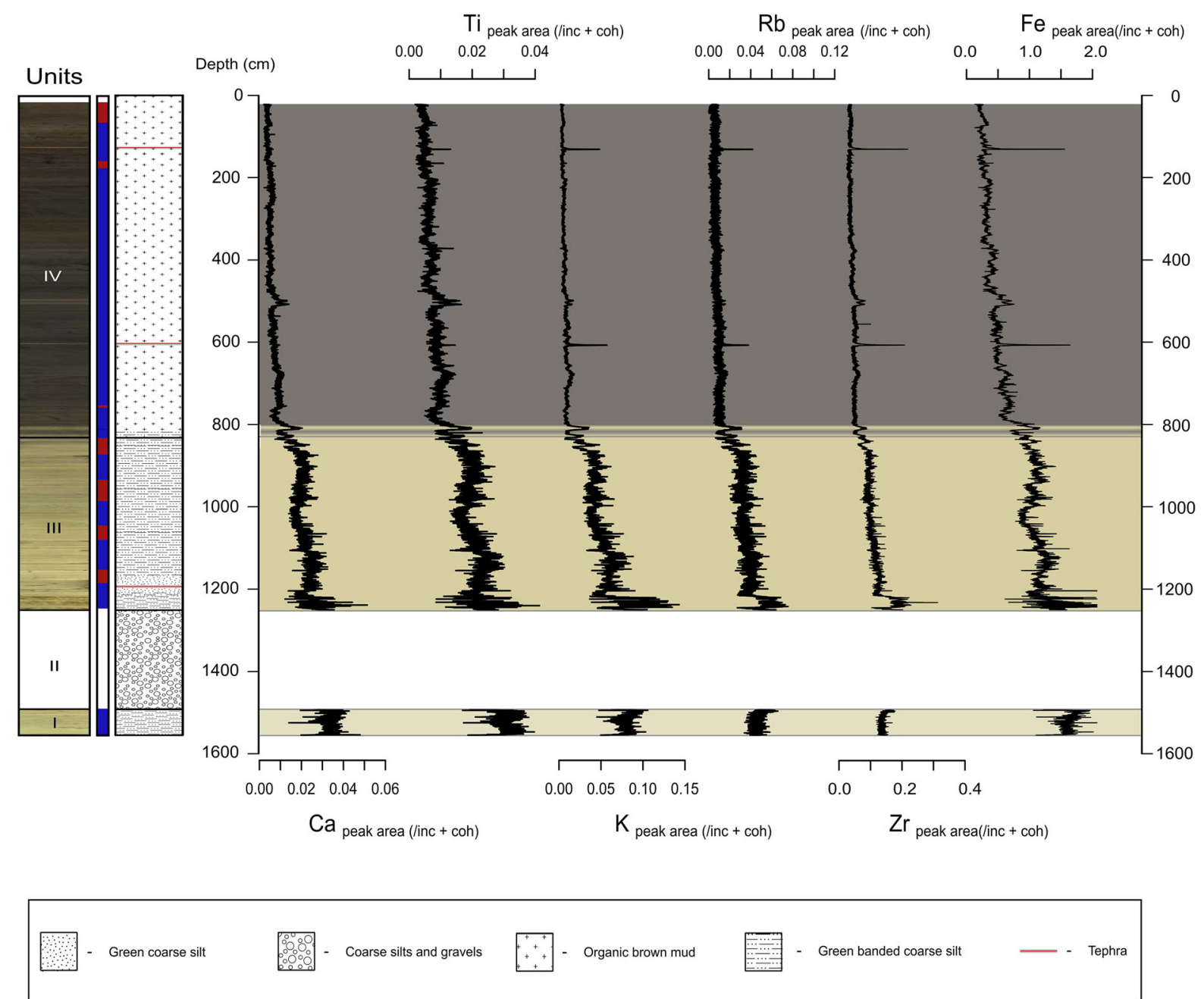

Fig. 2 Lithostratigraphy (Master core: $1 \mathrm{~B}=$ blue; $1 \mathrm{~A}=$ red) and XRF data for calcium $(\mathrm{Ca})$, titanium $(\mathrm{Ti})$, potassium $(\mathrm{K})$, rubidium $(\mathrm{Rb})$, zirconium $(\mathrm{Zr})$ and iron $(\mathrm{Fe})$

be distinguished from GGT-2 based on its higher Ba concentrations.

\section{Lead-210 activity and SCP}

Total ${ }^{210} \mathrm{~Pb}$ activity reaches equilibrium with supported ${ }^{210} \mathrm{~Pb}$ at a depth around $52 \mathrm{~cm}$ of the core. Unsupported ${ }^{210} \mathrm{~Pb}$ activities, calculated by subtracting ${ }^{226} \mathrm{Ra}$ activity (as supported ${ }^{210} \mathrm{~Pb}$ ) from total ${ }^{210} \mathrm{~Pb}$ activity, decline overall irregularly with depth (ESM1). The unsupported ${ }^{210} \mathrm{~Pb}$ activity profile shows two different sections: the top $19 \mathrm{~cm}$ section and the rest of the core. Within each individual section, unsupported ${ }^{210} \mathrm{~Pb}$ activities decline more or less exponentially with depth, suggesting a relatively uniform sedimentation rate within the sections. However, as the decline gradients in the two sections are different, sedimentation rates might have changed at around $19 \mathrm{~cm}$ depth.

The ${ }^{137} \mathrm{Cs}$ activity versus depth (ESM1) shows a well-resolved peak at $7.5 \mathrm{~cm}$. Such a ${ }^{137} \mathrm{Cs}$ peak has been found in other records from Eastern Africa (Panizzo et al. 2008; Stoof-Leichsenring et al. 2011). It is almost certain that this peak was derived from the 1963 fallout maximum of the atmospheric testing of nuclear weapons. A ${ }^{241} \mathrm{Am}$ activity at $7.5 \mathrm{~cm}$ suggests the fallout of nuclear weapon testing, although one single point is not sufficient for dating (ESM1).

SCP concentrations increase to above detection limit at $11.5 \mathrm{~cm}$ and increase rapidly to a peak of 
almost $1000 \mathrm{~g}^{-1}$ (per gram dry mass) at $4.5 \mathrm{~cm}$. Outside Europe and North America, such a profile is common, with the initial increase representing $1950 \pm 5$ years (Rose 2015). This would place $1950 \pm 5$ at $12 \mathrm{~cm}$ depth, in good agreement with the ${ }^{210} \mathrm{~Pb}$ chronology.

\section{Radiocarbon dating}

The 7 bulk $n$-alkane and 14 bulk sediment samples yielded sufficient carbon amounts of up to $138 \mu \mathrm{g}$ for ${ }^{14} \mathrm{C}$ dating (ESM1). Except for one $n$-alkane sample (low carbon mass of $16 \mu \mathrm{g}$ ), the bulk $n$-alkane and the bulk sediment samples obtained from the same core centimeters yielded similar ages without any systematic age offset. Additionally, there is no age offset for the three charcoal ${ }^{14} \mathrm{C}$ ages. Apart from macrocharcoal particles ( $>150$ microns particles), we found no other terrestrial macrofossils suitable for ${ }^{14} \mathrm{C}$ dating.

\section{Age-depth model and sedimentation rate}

To develop an age-depth model (Fig. 3), we combined the ${ }^{210} \mathrm{~Pb}$, bulk sediment, bulk $n$-alkane and charcoal
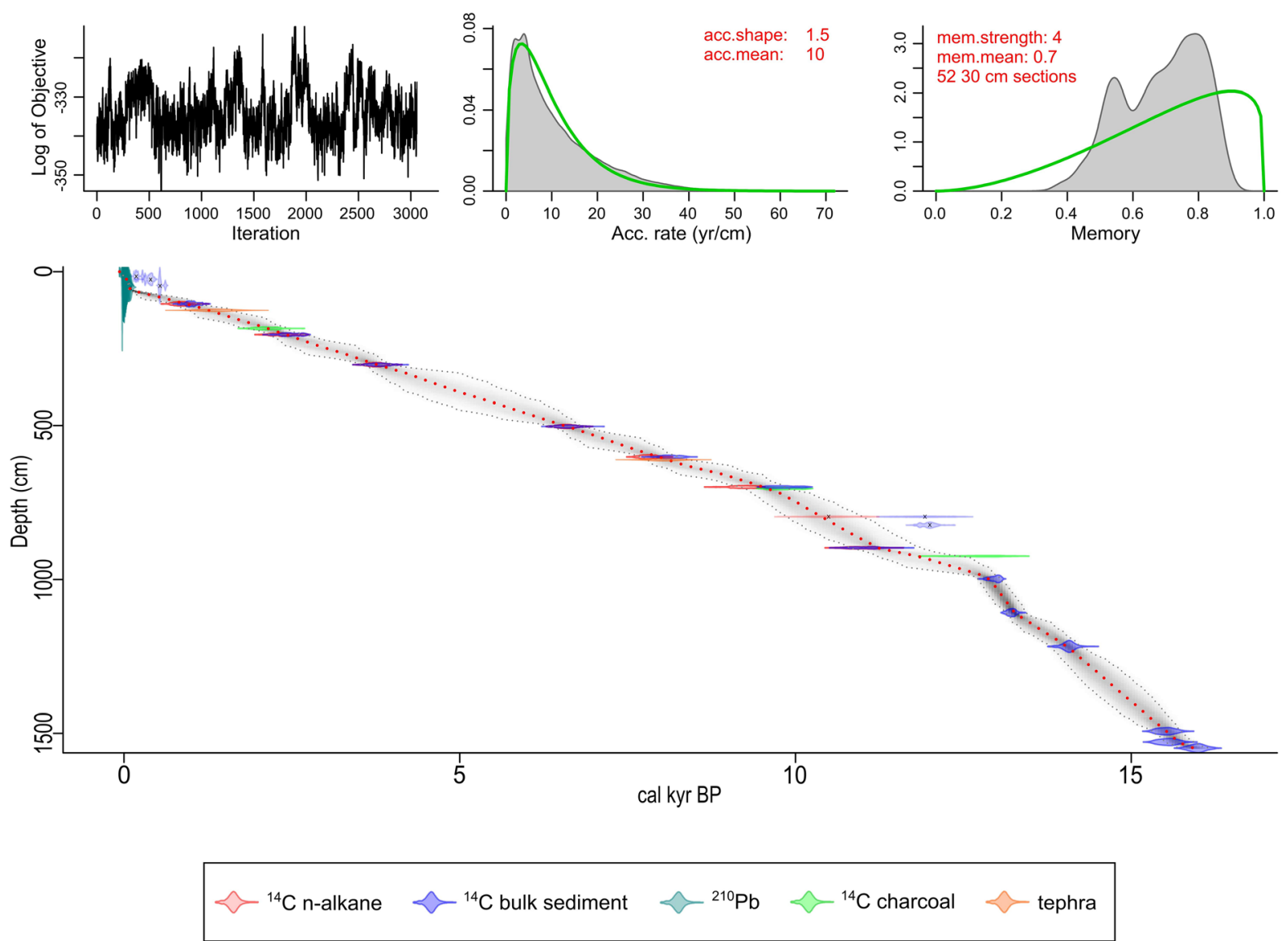

Fig. 3 Age-depth model for the Garba Guracha sedimentary record. The model was created using Bacon (Blaauw and Christen 2011). Top left: The log-likelihood of the model fit for the saved iterations of the model, Top middle: prior and posterior distribution of accumulation rate, and Top right: prior and posterior distribution of the autocorrelation in accumulation rates (memory). In the bottom left: The accumulation rate $(\mathrm{cm}$ $\mathrm{yr}^{-1}$ ) per time (cal Yr. BP.) The main panel displays the depth (x-axis) and age (y-axis) scale. The probability distribution of the calibrated ages is represented as violin plots. The probability of ageranges for any given depthis displayed in the greyshaded sections and thedotted lines around itrepresent the 95\% highestprobability density (tephra dating have $68 \%$ probability). Datings areshown in different colors. Shaded violin plotsmarked with " $x$ " showdatings excluded from theage-depth model. In thelower-left corner, thesedimentation rate with amean sedimentation rate(dotted red line) isdisplayed. (Color figure online) 


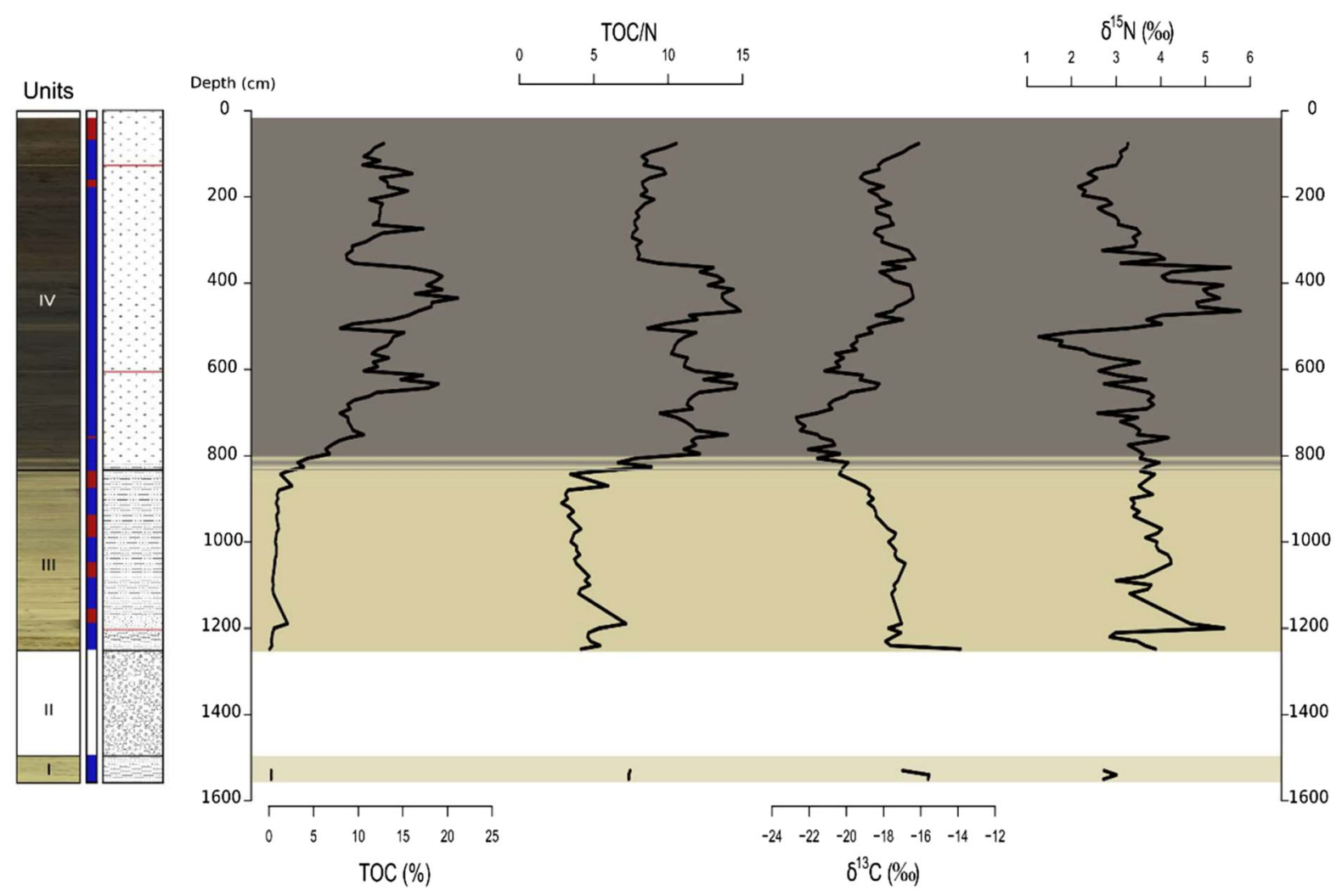

Fig. 4 Total organic carbon (TOC), carbon to nitrogen ratio (TOC/N) and stable carbon and nitrogen isotopic composition $\left(\delta^{13} \mathrm{C}\right.$ and $\left.\delta^{15} \mathrm{~N}\right)$

radiocarbon ages into a Bayesian modeling framework (Blaauw 2010; Blaauw and Christen 2011). Note that a preliminary version of this age-model underlies the paleoenvironmental dataset published by Gil-Romera et al. (2019). All ${ }^{14} \mathrm{C}$ ages with a carbon mass smaller than $19 \mu \mathrm{g}$ were rejected and not used for our agedepth model. Additionally, two ages that are not in stratigraphic order and three bulk sediment ${ }^{14} \mathrm{C}$ ages at the core top which have an age offset to the ${ }^{210} \mathrm{~Pb}$ dating were excluded but are displayed in Fig. 3 . According to the dating results and the established age-depth model, sedimentation in Garba Guracha started at about 15.9 cal kyr BP.

The mean sedimentation rate (MSR) for our BALGGU17-AB core is $1.25 \mathrm{~mm} \mathrm{a}^{-1}$ (Fig. 3). The highest average values of $2.90 \mathrm{~mm} \mathrm{a}^{-1}$ are recorded between $1110-990 \mathrm{~cm}$ with maximum values of $5 \mathrm{~mm} \mathrm{a}^{-1}$. A second maximum is present from 900 to $720 \mathrm{~cm}$ with a sedimentation rate of $1.27 \mathrm{~mm} \mathrm{a}^{-1}$. In between these maxima, a marked sedimentation minimum with decreased rates by up to $75 \%$ characterizes the time period from $12.8 \mathrm{cal}$ kyr BP to $11.3 \mathrm{cal} \mathrm{kyr}$ BP. From $720 \mathrm{~cm}$ on, the sedimentation rate decreases constantly until the present day with a mean sedimentation rate of $0.70 \mathrm{~mm} \mathrm{a}^{-1}$.

Establishing a robust chronology/sedimentation rate for the uppermost decimetres of the core is challenging because the combination of the two chronological methods provides us with a significant change in sedimentation rate that is most likely unrepresentative of the true sedimentation process. But since the modeled age is coherent with the sedimentation pattern of previous sections, and there is no significant change in any other proxies, we assume the radiocarbon- $\mathrm{Cs} / \mathrm{Pb}$ age-transition to be valid. Therefore, MSR for the topmost $65 \mathrm{~cm}$ is $5.4 \mathrm{~mm} \mathrm{a}^{-1}$. 
Geochemistry

\section{XRF scanning}

The XRF scanning of the elements $\mathrm{Rb}, \mathrm{K}, \mathrm{Ti}, \mathrm{Fe}, \mathrm{Ca}$, and $\mathrm{Zr}$ yielded the highest values in the lower part of the core with a stepwise decrease at $1200 \mathrm{~cm}$ and $800 \mathrm{~cm}$ to relatively low amounts. (Fig. 2). All these elements have a very high correlation coefficient of $r>0.93$. At $500 \mathrm{~cm}$ an increase of $\mathrm{Ca}$, $\mathrm{Ti}$ and $\mathrm{Fe}$ are coincide with low TOC values. Two short peaks in $\mathrm{Zr}$, $\mathrm{Rb}, \mathrm{K}$ and $\mathrm{Fe}$ reflect the tephra layers at $604 \mathrm{~cm}$ and $129 \mathrm{~cm}$, respectively.

\section{Organic geochemistry and stable isotope results}

TOC values for the Garba Guracha master core range from $0.3 \%$ to $21.4 \%$ (Fig. 4). Low TOC persists until $840 \mathrm{~cm}$. Above that depth, TOC values increase constantly until $355 \mathrm{~cm}$ with maxima at $630 \mathrm{~cm}$ $(19.2 \%)$ and $430 \mathrm{~cm}(21.4 \%)$ and a minimum at $500 \mathrm{~cm}$ of $8 \%$. At $355 \mathrm{~cm}$, TOC rapidly decreases to values $<10 \%$.

The $\mathrm{TOC} / \mathrm{N}$ ratios range from 2.8 to 14.9 . The lowest values prevail from the bottom of the core until $840 \mathrm{~cm}$. Until $355 \mathrm{~cm}$, relatively high ratios of up to 15 occur with short minima at 700 and $500 \mathrm{~cm}(9.5$ and 6.5 cal kyr BP). Maxima characterize the depth between 640 and 610 and 460 and $355 \mathrm{~cm}$.

The $\delta^{13} \mathrm{C}$ values range between -22.7 and $-13.9 \%$. A decline in $\delta^{13} \mathrm{C}$ to lowest values $(-22 \%)$, coincides with an increase in TOC and $\mathrm{TOC} / \mathrm{N}$ at $840 \mathrm{~cm}$, followed by generally increasing values until $420 \mathrm{~cm}$ with a strong decrease at $600 \mathrm{~cm}$. A small overall decrease continues to $160 \mathrm{~cm}$. This interval includes a strong maximum of $-16.3 \%$ at $340 \mathrm{~cm}$ and a weaker one $(-16.8 \%)$ at $355 \mathrm{~cm}$. An increase is visible from $160 \mathrm{~cm}$ to the top of the core.

The $\delta^{15} \mathrm{~N}$ values range from 1.3 to $5.8 \%$. From the bottom of the core to around $55 \mathrm{~cm}$ values stay stable around 3-4\%. A decrease with a minimum $(1.3 \%$ ) at $525 \mathrm{~cm}$ is followed by a maximum between 500 and $355 \mathrm{~cm}(4-5.8 \%$ ). Values decrease again until $170 \mathrm{~cm}$.
$P_{a q}$ and sugar ratios

Using the quantification of $n$-alkanes and sugar biomarkers, different ratios can be calculated to distinguish between terrestrial versus aquatic sources. Calculated ratios in this study cover the first $940 \mathrm{~cm}$ of the core due to insufficient organic matter content in the lower parts.

A common ratio for $n$-alkanes to differentiate aquatic macrophyte input versus emergent and terrestrial vegetation input is the $\mathrm{P}_{\mathrm{aq}}$ proxy (Ficken et al. 2000), defined as

$P_{\mathrm{aq}}=\frac{\left(n_{C 23}+n_{C 25}\right)}{\left(n_{C 23}+n_{C 25}+n_{C 29}+n_{C 21}\right)}$

The $\mathrm{P}_{\mathrm{aq}}$ ratio values range between 0.04 and 0.57 (Fig. 5). Highest values are present between 940 and $780 \mathrm{~cm}$ (up to 0.57 ) with one minimum at $840 \mathrm{~cm}$ (0.33). A shift to lower values occurs with a minimum at $750 \mathrm{~cm}(0.22)$ and a maximum at $500 \mathrm{~cm}(0.41)$. Like the TOC and TOC/N values the $\mathrm{P}_{\mathrm{aq}}$ decreases drastically at $355 \mathrm{~cm}$. Followed by a phase of low values until $260 \mathrm{~cm}$. The last $260 \mathrm{~cm}$ have intermediate values with a minimum at $155 \mathrm{~cm}(0.04)$.

Hepp et al. (2016) developed two sugar biomarker ratios defined as fuc/(ara $+x y l)$ and fuc/(ara $+x y l)$.

The fuc/(ara $+x y l)$ ratios range from 0.2 to 0.8 (Fig. 5). The highest values concur with the highest values of the $\mathrm{P}_{\mathrm{aq}}$ ratio from 940 to $780 \mathrm{~cm}$ with a maximum at $795 \mathrm{~cm}(0.5)$. A more abrupt shift to lower values occurs at $770 \mathrm{~cm}$. Low values proceed until $260 \mathrm{~cm}$ with a maximum at $485 \mathrm{~cm}(0.6)$ and a minimum at $720 \mathrm{~cm}(0.3)$. After a maximum at $235 \mathrm{~cm}(0.5)$, the lowest values of the core prolong between 235 and $145 \mathrm{~cm}$. The last $140 \mathrm{~cm}$ are characterized by a strong increase with a maximum at $85 \mathrm{~cm}(0.58)$.

The (fuc $+x y l) / a r a$ ratios range between 0.7 and 3 (Fig. 5). The ratio correlates well with the fuc/ $($ ara $+x y l)$ ratio for the top $235 \mathrm{~cm}$ with minima at 145 and $195 \mathrm{~cm}$. The highest values are reached between 390 and $490 \mathrm{~cm}$ (up to 3). Low values at 690 to $740 \mathrm{~cm}$ correlate well with the fuc/(ara $+x y l)$ ratio. However, underneath $770 \mathrm{~cm}$ when the fuc/ $($ ara $+\mathrm{xyl})$ ratio shows the highest values the (fuc + 
Fig. 5 Ternary diagram illustrating the relative contributions of ara, fuc and xyl in the Garba Guracha sedimentary record. For comparision, plant, organic layer and topsoil samples from the Garba Guracha catchment are included (Mekonnen et al. 2019)

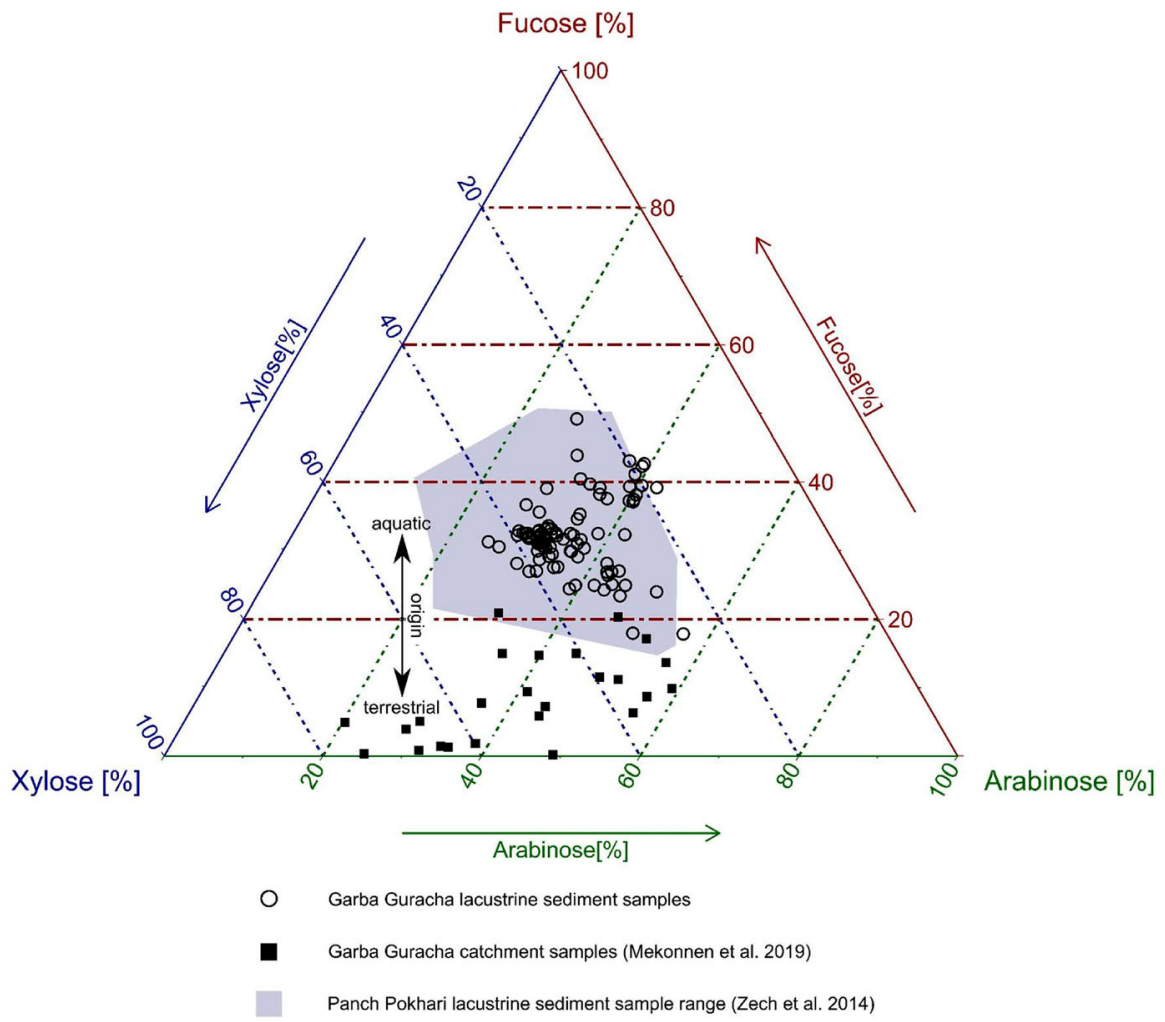

$\mathrm{xyl}$ )/ara ratio displays conditions with values between 1.3 and 1.9 .

\section{Discussion}

Chronology

\section{Tephra correlation}

Rhyolitic tephras, of similar composition to the Gurba Gurache tephras, have also been documented in Holocene sediment cores from the Main Ethiopian Rift lakes Tilo and Chamo (Martin-Jones et al. 2017). Fourteen tephra layers were identified in the $<10 \mathrm{kyr}$ Lake Tilo sequence by Martin-Jones et al. (2017), who geochemically correlated two of these horizons (TT-2 and TT-13) to two tephra layers occurring within sediments from Lake Chamo, $170 \mathrm{~km}$ to the south. Martin-Jones et al. (2017) suggested that the Corbetti caldera ( $\sim 40 \mathrm{~km}$ east of Lake Tilo), which erupts tephras of a distinct composition in comparison to other Ethiopian Rift volcanoes, is the source of the tephras found at lakes Tilo and Chamo. Fontijn et al.
(2018) later correlated TT-2 and TT-13 to their onland equivalents in outcrops within the Corbetti caldera, confirming this as the source for these two eruptions.

To test if the Garba Guracha tephras were also deposited by eruptions from Corbetti $(\sim 120 \mathrm{~km}$ to the west of our site) we compared the glass composition of GGT-1 and GGT-2 with the Tilo and Chamo tephras (ESM1). Tephra GGT-1 matches the composition of the Tilo tephra TT-2, which is dated at Lake Tilo to 1.3-1.5 cal kyrs BP. Martin-Jones et al. (2017) geochemically correlated TT-2 to the youngest of the Chamo tephras CHT-1 (1.5-1.9 cal kyrs BP), and this deposit represents Corbetti's most recent highly explosive eruption. Tephra GGT-2 has a similar composition to glass within the Tilo tephra TT-13 (dated at Tilo to 8.3-8.7 cal kyrs BP), which correlates to CHT-2 at Lake Chamo and where it is dated to 7.8-8.3 cal kyrs BP. GGT-1 and GGT-2 glass does, however, contain lower concentrations of $\mathrm{Zr}$, Th, and Ba than the Tilo and Chamo tephra glass shards. These eruptions may have tapped a compositionally stratified magma chamber resulting in wide-ranging tephra compositions. Garba Guracha is the first distal site to 
the east of Corbetti for which we have glass data, and if wind direction changed mid-eruption this could explain why we have a slightly different tephra compositions deposited in this new location.

Although the Corbetti tephras are compositionally zoned, making their recognition in different locations more challenging, the existing evidence for the widespread dispersal of tephras TT-2 and TT-13 supports our tentative geochemical correlations to the distal tephra layers preserved at Garba Guracha. Here we use these tephra correlations as an external test of the Garba Guracha age model. Whilst the tephra layers recorded in lakes Tilo and Chamo have greater uncertainties than the Garba Guracha tephras, these horizons act as useful markers around which we can compare environmental indicators recorded in the different lakes. Our correlations to the well-dated Garba Guracha record allow us to refine the ages of these two highly explosive Holocene eruptions from the Corbetti caldera.

\section{Age-depth model}

The 2017 Garba Guracha core covers the range from the present day to $\sim 15.9 \mathrm{cal} \mathrm{kyr} \mathrm{BP}$. Tiercelin et al. (2008) suggested the minimum age of deglaciation to be $\sim 16.7 \mathrm{cal} \mathrm{kyr} \mathrm{BP.} \mathrm{Exposure} \mathrm{dating}(15 \pm 1 \mathrm{cal}$ kyr BP) of bolders and glacial features in the Togona Valley (down hill from Garba Guracha) support a later minimum age of deglaciation (Ossendorf et al. 2019; Groos unpublished data). The modeled ages for the two tephra layers at 129 and $604 \mathrm{~cm}$ are 1.2-1.6 and 7.8-8.1 cal kyr BP, respectively. These tephra ages compare well with the ages of their geochemical correlatives (Fig. 3). The independent chronological context provided by the tephra layers on the Garba Guracha age model not only underlines the robustness of the age model but also allows us to conclude that the offset between ${ }^{14} \mathrm{C}$ bulk sediment and ${ }^{210} \mathrm{~Pb}$ ages in the top of the core (ESM1) is not a systematic age offset. Due to the fact that the ${ }^{210} \mathrm{~Pb}$ ages are supported by SCP and a hard water effect of the ${ }^{14} \mathrm{C}$ ages can be ruled out, we hypothesize the input of pre-aged terrestrial organic matter after $\sim 1$ cal kyr BP.

An old carbon input could also explain the stratigraphically inconsistent older ${ }^{14} \mathrm{C}$ bulk sediment ages at 794 and $821 \mathrm{~cm}$. Interestingly an $n$-alkane date at $794 \mathrm{~cm} \mathrm{(9.7-11.2} \mathrm{cal} \mathrm{kyr} \mathrm{BP),} \mathrm{which} \mathrm{has} \mathrm{been}$ excluded due to low carbon mass suggests a younger age more in agreement with the current age-depth model (Fig. 3). Higher runoff after 11.3 cal kyr BP (i.e. after the YD period) might have led to an input of old terrestrial organic matter with low $n$-alkane content (less vegetation during the YD cold phase). Therefore, bulk sediment could be more strongly preaged than the $n$-alkane component.

In the literature, pre-aging effects have been described for bulk sediment (Sirocko et al. 2013) and $n$-alkanes (Douglas et al. 2014; Gierga et al. 2016) because terrestrial material/biomarkers can be stored in soils for a long period before being transported into the sediment (Raymond and Bauer 2001). In soils or sediments, $n$-alkanes can be preserved due to their chemical inertness, resistance against degradation and low water solubility (Eglinton and Eglinton 2008). If the catchment area does not yield old carbon pools and the residence times for biomarkers are short, bulk $n$ alkane dating that was previously undertaken by (Bliedtner et al. 2020; Häggi et al. 2014; Haas et al. 2017; Zech et al. 2017) is hence corroborated as a valuable tool for dating lacustrine sediments in addition to compound-specific $n$-alkane ${ }^{14} \mathrm{C}$ dating (Gierga et al. 2016).

The small Garba Guracha catchment with poorly developed soils favors rapid sedimentation and $n$ alkane deposition without considerable pre-aging effects. A contribution of aeolian transported plantwaxes cannot be completely discounted, despite the negligible old carbon input. Yet, for most parts of the core, our ${ }^{14} \mathrm{C}$ results suggest that (i) either the terrestrial $n$-alkanes have a very short residence time in the catchment (ii) and/or the $n$-alkanes are primarily of the same allochthonous/autochthonous origin as the bulk sedimentary organic matter.

\section{Origin of organic matter}

Distinguishing between allochthonous (terrestrial) versus autochthonous (aquatic) OM is a crucial issue in paleolimnological studies (Brenner et al. 1999; Meyers 2003). For instance, $\mathrm{TOC} / \mathrm{N}$ ratios $<10$ (Meyers 2003) are frequently used as indicators for primarily autochthonous-derived OM. By contrast, terrestrial higher plants (due to a higher amount of carbon-rich lignin and cellulose) are typically characterized by higher TOC/N ratios (> 20) (Meyers 1994). It should be acknowledged, however, that degradation and mineralization of terrestrial OM result in lower 


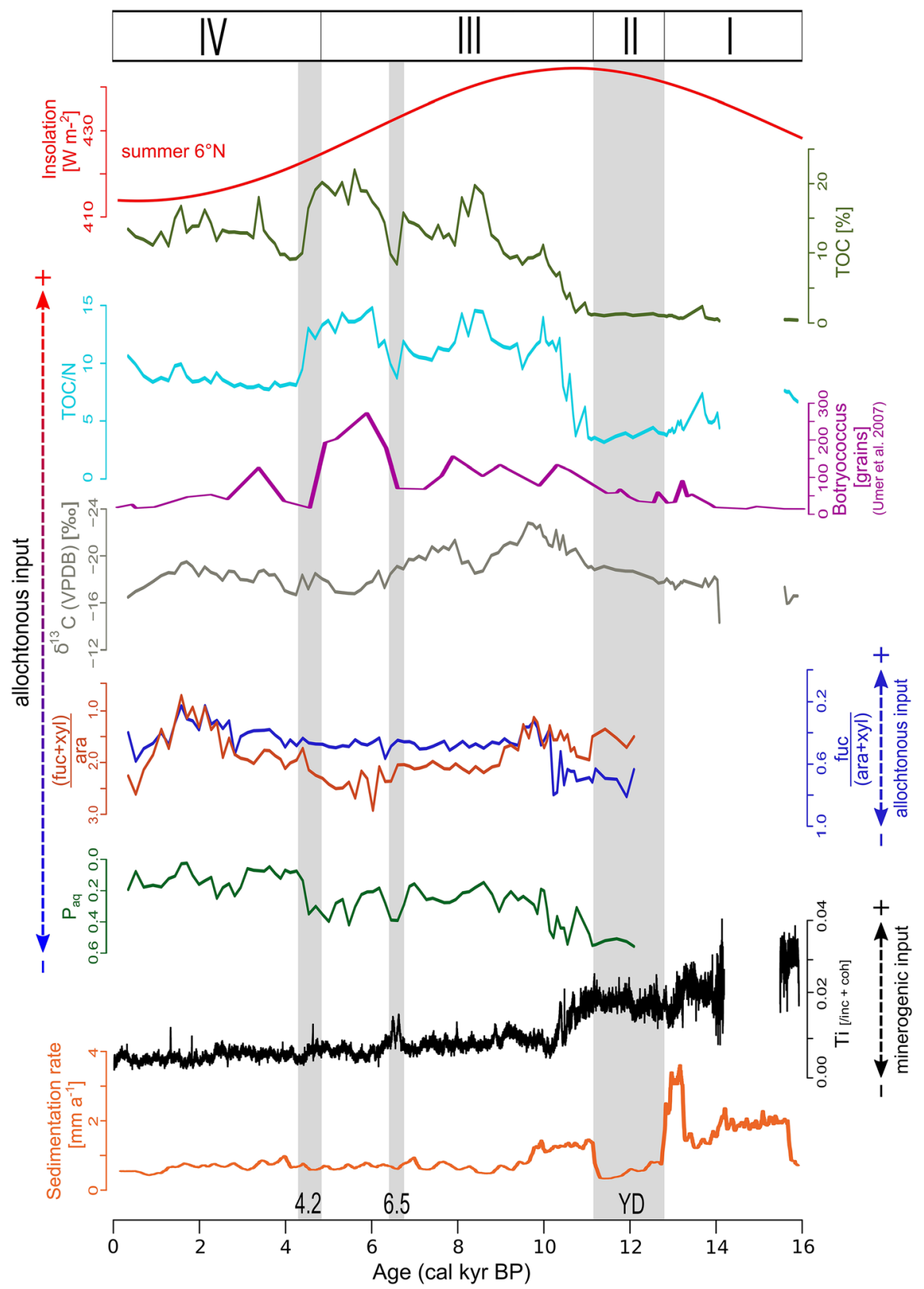

Fig. 6 Summer insolation (Laskar et al. 2004), TOC, TOC/N, Botryococcus braunii (Umer et al. 2007), $\delta^{13}$ C, (fuc + xyl)/ara, fuc/ $($ ara $+x y l), P_{a q}$, titan element and calculated sedimentation rate

TOC/N ratios, as well as in more positive $\delta^{13} \mathrm{C}$ values (Zech et al. 2007). In a study by Mekonnen et al. (2019), it is shown that the leaves of Erica in the Bale Mountains have very high TOC/N ratios of about 55, whereas $\mathrm{A}_{\mathrm{h}}$ horizons underneath Erica yielded TOC/N ratios of around 17. The TOC/N ratios of the Garba
Guracha core reveal a wide range from 2.8 to 14.9 (Fig. 6). While a predominantly allochthonous OM input can be excluded, a partial terrestrial OM input cannot be ruled out for the Early to Mid-Holocene. At the same time, the planktonic microalgae Botryococcus braunii became more abundant during the Early 
and Mid-Holocene with a clear maximum from 6.5 to 4.2 cal kyr BP (Umer et al. 2007) (Fig. 6). B. braunii is known for unusually high TOC/N ratios compared to other algae (Leng and Marshall 2004). This is confirmed by a $B$. braunii sample that we cultivated and that yielded a TOC/N ratio of 18 and a $\delta^{13} \mathrm{C}$ value of $-13.8 \%$. Higher TOC/N values due to a strong abundance of $B$. braunii may, therefore, be misinterpreted as an increase in allochthonous OM input.

According to Brenner et al. (2006) and O'Leary (1988), C3 vascular plants are characterized by $\delta^{13} \mathrm{C}$ values ranging between $-25 \%$ and $-35 \%$. By contrast, C4 plants are characterized by less negative $\delta^{13} \mathrm{C}$ values ranging between -16 to $-10 \%$ and algae can produce $\delta^{13} \mathrm{C}$ values up to $-12 \%$. Given that there is no evidence hitherto for the occurrence of $\mathrm{C} 4$ plants in our catchment (Mekonnen et al. 2019), the overall relatively positive $\delta^{13} \mathrm{C}$ values of Garba Guracha $(\geq-22.7 \%$, Fig. 6) support a dominant autochthonous OM input.

The use of $\delta^{15} \mathrm{~N}$ as proxy for $\mathrm{OM}$ origin can be problematic due to various possible nitrogen sources, the discrimination during denitrification and diagenesis (Brenner et al. 1999; Hepp et al. 2019).

Apart from bulk sedimentary OM, source identification can be done on a molecular level, too. Concerning $n$-alkane biomarkers, Ficken et al. (2000) introduced the $\mathrm{P}_{\mathrm{aq}}$ index based on the finding that submerged and floating aquatic plants from a lake on Mt. Kenya are characterized by values between 0.4 and 1 , whereas terrestrial plants yielded values lower than 0.1. According to this proxy, aquatic-derived $n$ alkanes dominate the YD sediments, a mixture of aquatic- and terrestrial-derived $n$-alkanes dominate the Early and Mid-Holocene sediments and terrestrialderived $n$-alkanes dominate at least partly the Late Holocene sediments (Fig. 6). However, we recommend caution when using the $\mathrm{P}_{\mathrm{aq}}$ proxy, because there is increasing evidence for potentially erroneous interpretations. While Hepp et al. (2018) emphasized the high production of the 'aquatic' $n$-alkane $n \mathrm{C}_{23}$ by birch rendering the $\mathrm{P}_{\mathrm{aq}}$ proxy invalid in European Late Glacial sedimentary archives, Baas et al. (2000) and Tarasov et al. (2013) report on high $n \mathrm{C}_{23}$ and $n \mathrm{C}_{25}$ concentrations of Sphagnum species, a fern and a sedge species. Moreover, the $\mathrm{P}_{\mathrm{aq}}$ interpretation for the Late Holocene part of Garba Guracha is clearly in contradiction with the TOC/N and $\delta^{13} \mathrm{C}$ interpretation (Fig. 6). At the current state of research, an unambiguous terrestrial versus aquatic source identification of the $n$-alkane record of Garba Guracha hence seems challenging.

Concerning the sugar biomarkers, Hepp et al. (2016) found terrestrial plants and mosses to be characterized by fuc/(ara $+x y l)$ ratios $<0.1$, whereas algae are characterized by ratios $>0.1$. The results for Garba Guracha (Fig. 6) thus suggest a predominantly aquatic (algae) origin of the sugars. This finding can also be nicely illustrated in a ternary diagram (Fig. 5) and highlights that the interpretation of predominantly aquatic-derived sugars is in good agreement with the 'aquatic' TOC/N and $\delta^{13} \mathrm{C}$ interpretation.

Environmental implications

Phase 1: (1548-995 cm; 16-12.8 cal kyr BP)

The highest values of the elements $\mathrm{Rb}, \mathrm{K}, \mathrm{Ti}, \mathrm{Fe}$, and $\mathrm{Zr}$ used to detect changes in minerogenic/lithogenic influx (Kylander et al. 2011), are likely representing relatively high minerogenic input attributable to glacial retreat in the catchment. In contrast to Tiercelin et al. (2008), we found no evidence for low sedimentation rates prevailing during the early Late Glacial; instead, we found high mean sedimentation rates of up to $1.86 \mathrm{~mm} \mathrm{a}^{-1}$. This implies a fast filling glacial cirque, potentially fed by a melting glacier forced by rising temperatures. Sparse vegetation in the catchment (Umer et al. 2007; Gil-Romera et al. 2019) and low algal productivity in the meltwater-fed lake could have been a small OM source represented by low TOC values of up to $1 \%$. Low TOC/N values of 5 and relatively positive $\delta^{13} \mathrm{C}$ values ( -19 to $14 \%$ ) point to aquatic algae as the dominant OM source (Meyers 2003; Brenner et al. 2006).

At $\sim 14$ cal kyr BP an increasing mean sedimentation rate of up to $2.2 \mathrm{~mm} \mathrm{a}^{-1}$ was dominated by detrital input as represented by high, but decreased, K, $\mathrm{Rb}, \mathrm{Ti}$, and $\mathrm{Zr}$ values which suggest continued, rapid in-filling of the lake fed by glacier retreat. Here our data and interpretation agrees with Tiercelin et al. (2008) in that the strong rise in sedimentation rate is due to stronger glacial recession probably caused by increasing temperatures and/or higher precipitation. 
Phase 2: (995-900 cm, 12.8-11.2 cal kyr BP)

During this interval sedimentation rates decreased dramatically by nearly $75 \%$ to $0.60 \mathrm{~mm} \mathrm{a}^{-1}$, indicating either a drier or colder climate. Cold conditions may have favored a longer season of ice-cover on the lake, whereas dry conditions would be associated with less runoff into the lake. In either scenario, we would expect to see not only a change in sedimentation but also a lower OM input into the lake. This is supported by low TOC values and decreased dominance of Erica heathlands, which, as revealed in the Garba Guracha pollen data, dominated the local vegetation during this phase (Umer et al. 2007; Gil-Romera et al. 2019). Additionally, aquatic production would likely have been reduced due to lower insolation during ice cover and lower input of nutrients.

This dry or/and cold period coincides with the YD in the Greenland ice cores (Alley 2000). The more precise timing of this phase of low sedimentation rate due to our robust and higher resolution chronology allows us to re-address previous discussions of the YD at Garba Guracha (Tiercelin et al. 2008). Younger Dryas-like conditions have been described in Eastern Africa before (Roberts et al. 1993; Talbot et al. 2007). Marshall et al. (2011) suggest likewise a phase of low sedimentation rate for Lake Tana during the YD due to reduced precipitation and runoff. During the YD, a weakening of the North Atlantic Deep Water formation, linked to increased freshwater input, is thought to have caused a sea surface temperature anomaly with reduced precipitation in the tropics and associated lake low stands (Street-Perrott and Perrott 1990). Climate modelling results (Chiang and Bitz 2005; Broccoli et al. 2006) support the idea of Nicholson (1982) that an interhemispheric thermal gradient forces the ITCZ south of the equator. A more recent modelling approach suggests a period of dry north winds during cold phases like Heinrich event 1 or YD (Mohtadi et al. 2014). Dry conditions coinciding with the YD have been reconstructed in several Eastern African lakes including Lake Victoria (Talbot and Lærdal 2000; Stager et al. 2002), Lake Suguta (Junginger et al. 2014), the Ziway-Shala basin (Gillespie et al. 1983), and Lake Albert (Beuning et al. 1997).
Phase 3: (900-340 cm, 11.2-4.5 cal kyr BP)

From the beginning of this phase until $10.8 \mathrm{cal}$ kyr BP, the mean sedimentation rate more than doubled to $1.37 \mathrm{~mm} \mathrm{a}^{-1}$. The reason for this may have been increasing temperatures due to higher insolation (Fig. 6) and increasing precipitation resulting in a stronger runoff. Both are supported by increasing TOC values and an higher hydrogen index (Tiercelin et al. 2008) pointing to more favorable conditions for aquatic and terrestrial OM production. Additionally, a change in $\mathrm{OM}$ production is recorded by an increasing TOC/N ratio from less than 5 to around 12. However, input of eroded old organic matter (formed during phase 2) cannot be ruled out.

After $10.8 \mathrm{cal} \mathrm{kyr}$ BP the sedimentation rate decreased slightly to $1.25 \mathrm{~mm} \mathrm{a}^{-1}$ until $9.8 \mathrm{cal} \mathrm{kyr}$ $\mathrm{BP}$ and in a second step more strongly to $0.72 \mathrm{~mm} \mathrm{a}^{-1}$. Additionally, lower $\mathrm{Ti}, \mathrm{Fe}, \mathrm{Ca}, \mathrm{K}$ and $\mathrm{Rb}$ counts and a TOC increase up to $18 \%$ indicate less minerogenic input and higher organic matter production. This change may be indicative of the progression of the catchment from a glacier-dominated catchment without vegetation to a cirque lake catchment with soil development and vegetation cover.

A drop of TOC and TOC/N ratios coincides with the 8.2 kyr event in the northern hemisphere, known as a short cold spell (Dansgaard et al. 1993; Bond et al. 1997). For this most pronounced climate shift in the Holocene, a period of drought has been reconstructed for the Ziway-Shala system (Gillespie et al. 1983), Lake Malawi (Gasse et al. 2002), and Lake Tilo (Leng et al. 1999). Thompson et al. (2002) found a maximum in wind-blown fluoride derived from dry lake basins in the Kilimanjaro ice record at $\sim 8.4$ cal kyr BP.

A pronounced TOC minimum with a drop to $10 \%$ coinciding with a tephra layer at $7.9 \mathrm{cal} \mathrm{kyr} \mathrm{BP}$ is followed by a phase of decreased TOC with a minimum of $8 \%$ at $6.5 \mathrm{cal} \mathrm{kyr} \mathrm{BP}$. At $6.5 \mathrm{cal} \mathrm{kyr} \mathrm{BP}$ a small maximum of higher minerogenic input marked by higher $\mathrm{Rb}, \mathrm{Ti}, \mathrm{Ca}$ and $\mathrm{K}$ counts concur with two organic poor layers in the core. Additionally, $\mathrm{P}_{\mathrm{aq}}$, fuc/ $($ ara $+x y l)$ and (fuc $+x y l) / a r a$ indicate a lower terrestrial OM input, which is supported by the reduced vegetation cover at that time in the lake's catchment (Gil-Romera et al. 2019). These findings represent a drought period, which is in agreement with an arid period found in a speleothem record in southern Oman (Fleitmann et al. 2007). 
Between 6 cal kyr BP and 4.5 cal kyr BP the highest OM production (TOC $\sim 20 \%$ ) of the core occurs. It coincides with the highest abundance of $B$. braunii (Umer et al. 2007), which could explain the highest TOC/N values of the entire core rather than an increased allochthounous $\mathrm{OM}$ input. A higher allochthounous $\mathrm{OM}$ input is contradicted by positive delta ${ }^{13} \mathrm{C}$ values in this phase which accompany a $B$. braunii increase. Blooms of $B$. braunii are associated with phosphorus availability due to high inwash (Huang and Hong 1999). This could point to a phase of increased nutrient availability and stronger aquatic productivity.

\section{Phase 4 (340-70 cm, 4.5-0.3 cal kyr BP)}

Contemporaneous with a strong decrease of $B$. braunii (Umer et al. 2007), TOC and the TOC/N ratio drop massively to $7 \%$ and 8 respectively. Less favorable conditions for $\mathrm{OM}$ in the Garba Guracha record coincide with a known drought phase due to a weak monsoon in the Indian ocean records (Fleitmann and Matter 2009; Nakamura et al. 2016) and aridity in North Africa (Gasse 2000; Marchant and Hooghiemstra 2004).

The $4.5 \mathrm{kyr}$ drought event is followed by a period of increased precipitation as evidenced by a slightly increased mean sedimentation rate to $0.85 \mathrm{~mm} \mathrm{a}^{-1}$ for around 1000 years before it decreases to $0.66 \mathrm{~mm} \mathrm{a}^{-1}$. TOC is around $15 \%$ with some variations and TOC/N decreases to 7-9. At 1.5 cal kyr BP minima in the $\mathrm{P}_{\mathrm{aq}}$, $\delta^{13} \mathrm{C}$ and sugar ratios point to an increased terrestrial $\mathrm{OM}$ production followed by an increase in aquatic production until the Little Ice Age at $\sim 0.6 \mathrm{cal} \mathrm{kyr}$ $\mathrm{BP}$ represented in the sugar biomarker ratios.

The high-altitude Garba Guracha archive reflects local and supraregional climate changes beginning with deglaciation at around $15.9 \mathrm{cal} \mathrm{kyr} \mathrm{BP}$ pointing to a temperature increase as a consequence of rising insolation (Laskar et al. 2004). This temperature increase may have been even stronger compared to low land ecosystems (Loomis et al. 2017). Increasing temperatures and precipitation at the beginning of phase 3 led not only to favorable conditions for OM production after the YD (phase 2) but also to prolonged humid conditions (phase 3) due to an enhancement of East and West African monsoon intensity in contrast to the reduced monsoonal activity during the YD (Umer et al. 2007) and a change in atmospheric circulation (Tierney et al. 2011; Costa et al. 2014; Junginger et al. 2014). This coincides with the AHP (deMenocal et al. 2000) and rising lake levels in Eastern Africa (Gasse 2000; Junginger et al. 2014; Lezine et al. 2014). A shift to arid conditions at $4.5 \mathrm{kyr}$ may mark a late termination of the AHP in the Garba Guracha record and may indicate a late response of a high-altitude aquatic system. However, Erica pollen already decreased at $5.2 \mathrm{kyr}$ (Gil-Romera et al. 2019). A return to wetter conditions between 2.5 and $1.5 \mathrm{kyr}$ concurs with rising lake levels in the Horn of Africa region (Lezine et al. 2014).

\section{Comparison with lake level and other records}

Garba Guracha appears to have reacted sensitively to local and supraregional climate changes. Despite favourable conditions for OM production are indicated by TOC and TOC/N, we should be careful when interpreting $\mathrm{TOC}$ and $\mathrm{TOC} / \mathrm{N}$ as climate proxies because local factors may overprint supraregional climate change effects on these proxies. For example, a TOC decrease at 7.9 cal kyr BP coincides with a volcanic eruption (GGT-1 tephra), and TOC increases may be explained for instance by high algal production (Umer et al. 2007).

However, the inferred timing of favorable conditions in the Early to Mid-Holocene for OM production (TOC and TOC/N) shows similarities with a TOC record from Lake Turkana (Morrissey and Scholz 2014) and coincides with lake level fluctuations of Lake Turkana (Garcin et al. 2012; Bloszies et al. 2015; Beck et al. 2019), Lake Suguta (Junginger et al. 2014), Chew Bahir (Foerster et al. 2012), Lake Abhé (Gasse 2000), Lake Dendi (Wagner et al. 2018), and Lake Ziway-Shala (Gillespie et al. 1983). The offset shown in our record at the Holocene onset may be altituderelated as during deglaciation, high-altitude climate records might be buffered due to slow melting of the remaining ice in the catchment, especially given the northward aspect of Garba Guracha (Tiercelin et al. 2008). Several minima in our TOC and TOC/N record coincide with drought phases in other Eastern African and Oman records at $10.7 \mathrm{cal}$ kyr BP (Junginger et al. 2014; Wagner et al. 2018), 8.2 cal kyr BP (Gasse 2000; Garcin et al. 2012; Costa et al. 2014; Junginger et al. 2014) and 6.5 cal kyr BP (Fleitmann et al. 2007). The decrease of TOC and TOC/N values at $4.5 \mathrm{cal} \mathrm{kyr}$ 
BP concurs better with the North-Ethiopian lake records (Lake Ziway-Shala (Gillespie et al. 1983) and Lake Abhé (Gasse 2000)) than with the SouthEthiopian lake records (Junginger et al. 2014).

Moreover, it has been shown that the timing of the AHP termination depends not only on the archive but on the investigated proxy (Castañeda et al. 2016). This holds true for the Garba Guracha archive with the decline of Erica pollen already beginning at $5.2 \mathrm{cal}$ kyr BP (Gil-Romera et al. 2019), 700 years earlier than the TOC and TOC/N record. An AHP termination at 5.2 cal kyr BP would concur with South-Ethiopian lake records (Junginger et al. 2014).

The different response of lake records in Eastern Africa during the Holocene might be explained, despite local factors, by two possible mechanisms: (1) an increase of atmospheric moisture depending on the ITCZ shift and thus on insolation and (2) an eastward shift of the Congo Air Boundary due to an enhanced pressure gradient between India and Eastern Africa (Tierney et al. 2011; Costa et al. 2014; Junginger et al. 2014; Castañeda et al. 2016). Due to the blurring of local factors on TOC and TOC/N and the different timing of proxies in connection with the AHP termination, further research, and other proxies, especially water isotopes, may be needed to help disentangle the conflicting evidence.

\section{Conclusions}

Garba Guracha provides one of the best dated Late Glacial - Holocene continuous high-altitude records in Eastern Africa. It offers a relatively small, undisturbed catchment where global and local climate influences can be studied. New sedimentary data and a more detailed and robust chronology give new insights into the sedimentary history and the catchment dynamics of Garba Guracha.

The chronology of the Garba Guracha record spans the last ca. 16 cal kyr BP. Bulk sediment and bulk $n$ alkane dates are in good agreement with charcoal and tephra ages. $n$-Alkane ages show no age offset to ${ }^{14} \mathrm{C}$ bulk sediment dating. We propose that a pre-aging effect for terrestrial $n$-alkanes or terrestrial material, in general, is negligible for most of the record due to short residence times for terrestrial material in the small catchment area and due to the high lake productivity. We conclude that our chronology is robust and that dating of bulk $n$-alkanes is a valuable tool for lake sediment dating in small catchment areas. The Garba Guracha sedimentary archive records the environmental change from deglaciation to a precipitation-fed lake. The record shows well-known climate changes such as the YD and the arid $\sim 6.5$ and $\sim 4.2$ kyr events. The occurrence of these events clearly shows regional and northern hemispheric influence on the high-altitude Eastern African ecosystems. Since the Holocene onset, organic-rich sediments point to climatic conditions favorable for aquatic biomass production due to higher temperatures and increased precipitation.

The high resolution environmental and chronological data presented in this study, alongside the uniqueness of the Garba Guracha site, allow us to pick out the complexity of past climates in the Ethiopian Rift and highlands. Our data suggest similarities between Garba Guracha and other sites in the region, but clearly there are temporal and spatial variations in how the past climate changes are manifested. Future publications and further study using a wider network of sites may enable us to understand leads and lags in the past climates of Eastern Africa in greater depth.

Acknowledgments Open Access funding provided by Projekt DEAL. This research was funded by the German Research Council (DFG) in the framework of the joint Ethio-European DFG Research Unit 2358 "The Mountain Exile Hypothesis. How humans benefited from and re-shaped African highaltitude ecosystems during Quaternary climate changes". We thank the Ethiopian Wildlife Conservation Authority for permitting our research in the Bale Mountains National Park. We are grateful to the project coordination, the Philipps University Marburg, University of Addis Abeba, the Frankfurt Zoological Society, the Ethiopian Wolf Project, the Bale Mountains National Park, and the related staff members, especially Katinka Thielsen, Mekbib Fekadu, Bahru Zinaye Asegahegn, Elias Tadesse, Ermias Getachew, and Terefe Endale, for their logistic assistance during our fieldwork. CMJ was supported by the Geography Laboratories, Cambridge, and thanks Iris Buisman (Cambridge) and Emma Tomlinson (Trinity College, Dublin) for guidance with tephra analysis. We thank the team of the Soil Biogeochemistry Department at Martin Luther University Halle Saale for the support during lab work, in particular, Marianne Benesch and Heike Maennike.

Open Access This article is licensed under a Creative Commons Attribution 4.0 International License, which permits use, sharing, adaptation, distribution and reproduction in any medium or format, as long as you give appropriate credit to the original author(s) and the source, provide a link to the Creative Commons licence, and indicate if changes were made. The 
images or other third party material in this article are included in the article's Creative Commons licence, unless indicated otherwise in a credit line to the material. If material is not included in the article's Creative Commons licence and your intended use is not permitted by statutory regulation or exceeds the permitted use, you will need to obtain permission directly from the copyright holder. To view a copy of this licence, visit http://creativecommons.org/licenses/by/4.0/.

\section{References}

Alley RB (2000) The Younger Dryas cold interval as viewed from central Greenland. Quat Sci Rev 19:213-226

Allison LE (1960) Wet combustion apparatus and procedure for organic and inorganic carbon in soils. Soil Sci Am 24:36-40

Amelung W, Cheshire MV, Guggenberger G (1996) Determination of neutral and acidic sugars in soil by capillary gasliquid chromatography after trifluoroacetic acid hydrolysis. Soil Biol Biochem 28:1631-1639

Andrews MA (1989) Capillary gas-chromatographic analysis of monosaccharides: Improvements and comparisons using trifluoroacetylation and trimethylsilylation of sugar O-benzyl- and O-methyl-oximes. Carbohydr Res 194:1-19

Appleby PG (2001) In: Last WM, Smol JP (eds) Chronostratigraphic Techniques in Recent Sediments BT-Tracking Environmental Change Using Lake Sediments: Basin Analysis, Coring, and Chronological Techniques. Springer, Dordrecht, pp 171-203

Appleby PG, Richardson N, Nolan PJ (1992) Self-absorption corrections for well-type germanium detectors. Nucl Instrum Methods Phys Res Sect B Beam Interact Mater Atoms 71:228-233

Appleby PG, Nolan PJ, Gifford DW, Godfrey MJ, Oldfield F, Anderson NJ, Battarbee RW (1986) 210Pb dating by low background gamma counting. Hydrobiologia 143:21-27

Baas M, Pancost R, van Geel B, Sinninghe Damsté JS (2000) A comparative study of lipids in Sphagnum species. Org Geochem 31:535-541

Beck CC, Feibel CS, Wright JD, Mortlock RA (2019) Onset of the African humid period by $13.9 \mathrm{kyr}$ BP at Kabua Gorge, Turkana Basin, Kenya. Holocene 29:1011-1019

Beuning KRM, Talbot MR, Kelts K (1997) A revised 30,000year paleoclimatic and paleohydrologic history of Lake Albert, East Africa. Palaeogeogr Palaeoclimatol Palaeoecol 136:259-279

Blaauw M (2010) Methods and code for 'classical' age-modelling of radiocarbon sequences. Quat Geochronol 5:512-518

Blaauw M, Christen JA (2011) Flexible paleoclimate age-depth models using an autoregressive gamma process. Bayesian Anal 6:457-474

Blaauw M, Bakker R, Christen JA, Hall VA, van der Plicht J (2007) A Bayesian framework for age modeling of radiocarbon-dated peat deposits: case studies from the Netherlands. Radiocarbon 49:357-367

Bloszies C, Forman SL, Wright DK (2015) Water level history for Lake Turkana, Kenya in the past 15,000 years and a variable transition from the African humid period to holocene aridity. Glob Planet Change 132:64-76

Bliedtner M, von Suchodoletz H, Schäfer I, Welte C, Salazar G, Szidat S, Haas M, Dubois N, Zech R (2020) Age and origin of leaf wax nalkanes in fluvial sediment-paleosol sequences and implications for paleoenvironmental reconstructions. Hydrol Earth Syst Sci 24:2105-2120

Bond G, Showers W, Cheseby M, Lotti R, Almasi P, deMenocal P, Priore P, Cullen H, Hajdas I, Bonani G (1997) A pervasive Millennial-scale cycle in north Atlantic holocene and glacial climates. Science 278(80):1257-1266

Brandt SA, Fisher EC, Hildebrand EA, Vogelsang R, Ambrose SH, Lesur J, Wang H (2012) Early MIS 3 occupation of Mochena Borago Rockshelter, Southwest Ethiopian Highlands: implications for late pleistocene archaeology, paleoenvironments and modern human dispersals. Quat Int 274:38-54

Brenner M, Hodell DA, Leyden BW, Curtis JH, Kenney WF, Gu B, Newman JM (2006) Mechanisms for organic matter and phosphorus burial in sediments of a shallow, subtropical, macrophyte-dominated lake. J Paleolimnol 35:129-148

Brenner M, Whitmore TJ, Curtis JH, Hodell DA, Schelske CL (1999) Stable isotope ( $\delta 13 \mathrm{C}$ and $\delta 15 \mathrm{~N})$ signatures of sedimented organic matter as indicators of historic lake trophic state. J Paleolimnol 22:205-221

Broccoli AJ, Dahl KA, Stouffer RJ (2006) Response of the ITCZ to Northern Hemisphere cooling. Geophys Res Lett 33

Castañeda IS, Schouten S, Pätzold J, Lucassen F, Kasemann S, Kuhlmann H, Schefuß E (2016) Hydroclimate variability in the Nile river basin during the past 28,000 years. Earth Planet Sci Lett 438:47-56

Chiang JCH, Bitz CM (2005) Influence of high latitude ice cover on the marine Intertropical Convergence Zone. Clim Dyn 25:477-496

Coplen TB (2011) Guidelines and recommended terms for expression of stable-isotope-ratio and gas-ratio measurement results. Rapid Commun Mass Spectrom $25: 2538-2560$

Costa K, Russell J, Konecky B, Lamb H (2014) Isotopic reconstruction of the African Humid Period and Congo Air Boundary migration at Lake Tana, Ethiopia. Quat Sci Rev 83:58-67

CRAN R Core Team (2014) R: A language and environment for statistical computing. R Foundation for Statistical Computing, Vienna, Austria

Croudace I, Rindby A, Guy Rothwell R (2006) ITRAX: description and evaluation of a new multi-function X-ray core scanner. Geol Soc London, Spec Publ 267:51-63

Dansgaard W, Johnsen SJ, Clausen HB, Dahl-Jensen D, Gundestrup NS, Hammer CU, Hvidberg CS, Steffensen JP, Sveinbjörnsdottir AE, Jouzel J, Bond G (1993) Evidence for general instability of past climate from a $250-\mathrm{kyr}$ icecore record. Nature 364:218-220

deMenocal P, Ortiz J, Guilderson T, Adkins J, Sarnthein M, Baker L, Yarusinsky M (2000) Abrupt onset and termination of the African Humid Period: rapid climate responses to gradual insolation forcing. Quat Sci Rev 19:347-361

Douglas PMJJ, Pagani M, Eglinton TI, Brenner M, Hodell DA, Curtis JH, Ma KF, Breckenridge A (2014) Pre-aged plant waxes in tropical lake sediments and their influence on the 
chronology of molecular paleoclimate proxy records. Geochim Cosmochim Acta 141:346-364

Eglinton TI, Eglinton G (2008) Molecular proxies for paleoclimatology. Earth Planet Sci Lett 275:1-16

Ficken KJ, Li B, Swain DL, Eglinton G (2000) An n-alkane proxy for the sedimentary input of submerged/floating freshwater aquatic macrophytes. Org Geochem 31:745-749

Fleitmann D, Matter A (2009) The speleothem record of climate variability in Southern Arabia. Comptes Rendus Geosci 341:633-642

Fleitmann D, Burns SJ, Mangini A, Mudelsee M, Kramers J, Villa I, Neff U, Al-Subbary AA, Buettner A, Hippler D, Matter A (2007) Holocene ITCZ and Indian monsoon dynamics recorded in stalagmites from Oman and Yemen (Socotra). Quat Sci Rev 26:170-188

Foerster V, Junginger A, Langkamp O, Gebru T, Asrat A, Umer M, Lamb HF, Wennrich V, Rethemeyer J, Nowaczyk N, Trauth MH, Schaebitz F (2012) Climatic change recorded in the sediments of the Chew Bahir basin, southern Ethiopia, during the last 45,000 years. Quat Int 274:25-37

Fontijn K, McNamara K, Zafu Tadesse A, Pyle DM, Dessalegn F, Hutchison W, Mather TA, Yirgu G (2018) Contrasting styles of post-caldera volcanism along the Main Ethiopian Rift: implications for contemporary volcanic hazards. J Volcanol Geotherm Res 356:90-113

Garcin Y, Melnick D, Strecker MR, Olago D, Tiercelin J-J (2012) East African mid-Holocene wet-dry transition recorded in palaeo-shorelines of Lake Turkana, northern Kenya Rift. Earth Planet Sci Lett 331-332:322-334

Gasse F, Barker P, Johnson TC (2002) A 24,000 yr Diatom Record from the Northern Basin of Lake Malawi BT. In: Odada EO, Olago DO (eds) The East African Great Lakes: limnology, palaeolimnology and biodiversity. Springer, Dordrecht, pp 393-414

Gasse F (2000) Hydrological changes in the African tropics since the Last Glacial Maximum. Quat Sci Rev 19:189-211

Gierga M, Hajdas I, van Raden UJ, Gilli A, Wacker L, Sturm M, Bernasconi SM, Smittenberg RH (2016) Long-stored soil carbon released by prehistoric land use: evidence from compound-specific radiocarbon analysis on Soppensee lake sediments. Quat Sci Rev 144:123-131

Gil-Romera G, Adolf C, Benito Blas M, Bittner L, Johansson M, Grady D, Lamb H, Lemma B, Fekadu M, Glaser B, Mekonnen B, Sevilla-Callejo M, Zech M, Zech W, Miehe G (2019) Long-term fire resilience of the Ericaceous Belt, Bale Mountains. Ethiopia Biol Lett 15:20190357

Gillespie R, Street-Perrott FA, Switsur R (1983) Post-glacial arid episodes in Ethiopia have implications for climate prediction. Nature 306:680-683

Haas M, Bliedtner M, Borodynkin I, Salazar G, Szidat S, Eglinton TI, Zech R (2017) Radiocarbon dating of leaf waxes in the Loess-Paleosol sequence Kurtak, central Siberia. Radiocarbon 59:165-176

Häggi C, Zech R, McIntyre C, Zech M, Eglinton TI (2014) On the stratigraphic integrity of leaf-wax biomarkers in loess paleosols. Biogeosciences 11:2455-2463

Hepp J, Wüthrich L, Bromm T, Bliedtner M, Schäfer IK, Glaser B, Rozanski K, Sirocko F, Zech R, Zech M (2019) How dry was the Younger Dryas? Evidence from a coupled $\delta^{2} \mathrm{H}-$ $\delta^{18} \mathrm{O}$ biomarker paleohygrometer applied to the
Gemündener Maar sediments, Western Eifel, Germany. Clim Past 15:713-733

Hepp J, Wüthrich L, Bromm T, Bliedtner M, Schäfer IK, Glaser B (2018) Reply to D. Sachse and F. Schenk (SC4: Data analysis and paleoclimatic context). Clim Past Discussions

Hepp J, Rabus M, Anhäuser T, Bromm T, Laforsch C, Sirocko F, Glaser B, Zech M (2016) A sugar biomarker proxy for assessing terrestrial versus aquatic sedimentary input. Org Geochem 98:98-104

Hillman J (1988) The Bale Mountains National Park Area, Southeast Ethiopia, and Its Management

Hillman J (1986) Conservation in Bale Mountains National Park, Ethiopia

Huang B, Hong H (1999) Alkaline phosphatase activity and utilization of dissolved organic phosphorus by Algae in subtropical coastal waters. Mar Pollut Bull 39:205-211

Jochum KP, Stoll B, Herwig K, Willbold M, Hofmann AW, Amini M, Aarburg S, Abouchami W, Hellebrand E, Mocek B, Raczek I, Stracke A, Alard O, Bouman C, Becker S, Dücking M, Brätz H, Klemd R, de Bruin D, Canil D, Cornell D, de Hoog C-J, Dalpé C, Danyushevsky L, Eisenhauer A, Gao Y, Snow JE, Groschopf N, Günther D, Latkoczy C, Guillong M, Hauri EH, Höfer HE, Lahaye Y, Horz K, Jacob DE, Kasemann SA, Kent AJR, Ludwig T, Zack T, Mason PRD, Meixner A, Rosner M, Misawa K, Nash BP, Pfänder J, Premo WR, Sun WD, Tiepolo M, Vannucci R, Vennemann T, Wayne D, Woodhead JD (2006) MPI-DING reference glasses for in situ microanalysis: New reference values for element concentrations and isotope ratios. Geochemistry, Geophys Geosystems, p 7

Junginger A, Roller S, Olaka LA, Trauth MH (2014) The effects of solar irradiation changes on the migration of the Congo Air Boundary and water levels of paleo-Lake Suguta, Northern Kenya Rift, during the African Humid Period (15-5 ka BP ) CA. Palaeogeogr Palaeoclimatol Palaeoecol 396:1-16

Kidane Y, Stahlmann R, Beierkuhnlein C (2012) Vegetation dynamics, and land use and land cover change in the Bale Mountains, Ethiopia. Environ Monit Assess 184

Kuzmicheva E, Jebessa Debella H, Khasanov B, Krylovich O, Girmay W, Vasyukov D, Yirga S, Savinetsky A (2017) Ecosystem histroy of the Bale Mountains. Ethiop J Biol Sci 16:61-94

Kylander ME, Ampel L, Wohlfarth B, Veres D (2011) Highresolution X-ray fluorescence core scanning analysis of Les Echets (France) sedimentary sequence: new insights from chemical proxies. J Quat Sci 26:109-117

Lamb HF, Bates CR, Bryant CL, Davies SJ, Huws DG, Marshall MH, Roberts HM, Toland H (2018) 150,000-year palaeoclimate record from northern Ethiopia supports early, multiple dispersals of modern humans from Africa. Sci Rep 8:1077

Laskar J, Robutel P, Joutel F, Gastineau M, Correia ACM, Levrard B (2004) A long-term numerical solution for the insolation quantities of the Earth. A\&A 428:261-285

Leng MJ, Marshall JD (2004) Palaeoclimate interpretation of stable isotope data from lake sediment archives. Quat Sci Rev 23:811-831

Leng MJ, Lamb AL, Lamb HF, Telford RJ (1999) Palaeoclimatic implications of isotopic data from modern and early 
Holocene shells of the freshwater snail Melanoides tuberculata, from lakes in the Ethiopian Rift Valley. J Paleolimnol 21:97-106

Lezine A-M, Bassinot F, Peterschmitt JYJ-Y, Lézine AM, Bassinot F, Peterschmitt JYJ-Y (2014) Orbitally-induced changes of the Atlantic and Indian monsoons over the past 20,000 years: New insights based on the comparison of continental and marine records. Bull la Soc Geol Fr 185:3-12

Löffler H (1978) Limnology and paleolimnological data on the Bale Mountain Lakes. Verth, Int Verein Limnol 20:1131-1138

Loomis SE, Russell JM, Verschuren D, Morrill C, De Cort G, Sinninghe Damsté JS, Olago D, Eggermont H, StreetPerrott FA, Kelly MA (2017) The tropical lapse rate steepened during the Last Glacial Maximum. Sci Adv 3:e1600815

Löwemark L, Chen H-F, Yang T-N, Kylander M, Yu E-F, Hsu Y-W, Lee T-Q, Song S-R, Jarvis S (2011) Normalizing XRF-scanner data: a cautionary note on the interpretation of high-resolution records from organic-rich lakes. J Asian Earth Sci 40:1250-1256

Marchant R, Hooghiemstra H (2004) Rapid environmental change in African and South American tropics around 4000 years before present: a review. Earth-Science Rev 66:217-260

Marshall MH, Lamb HF, Huws D, Davies SJ, Bates R, Bloemendal J, Boyle J, Leng MJ, Umer M, Bryant C (2011) Late Pleistocene and Holocene drought events at Lake Tana, the source of the Blue Nile. Glob Planet Change 78:147-161

Martin-Jones CM, Lane CS, Pearce NJG, Smith VC, Lamb HF, Schaebitz F, Viehberg F, Brown MC, Frank U, Asrat A (2017) Recurrent explosive eruptions from a high-risk Main Ethiopian Rift volcano throughout the Holocene. Geology 45:1127-1130

Mekonnen B, Zech W, Glaser B, Lemma B, Bromm T, Nemomissa S, Bekele T, Zech M (2019) Chemotaxonomic patterns of vegetation and soils along altitudinal transects of the Bale Mountains, Ethiopia, and implications for paleovegetation reconstructions-Part 1: stable isotopes and sugar biomarkers. E\&G Quat Sci J 68:177-188

Meyers PA (2003) Applications of organic geochemistry to paleolimnological reconstructions: a summary of examples from the Laurentian Great Lakes. Org Geochem 34:261-289

Meyers PA (1994) Preservation of elemental and isotopic source identification of sedimentary organic matter. Chem Geol 114:289-302

Miehe S, Miehe G (1994) Ericaceous forests and heathlands in the Bale mountains of South Ethiopia : ecology and man's impact. Warnke, Reinbek, Reinbek

Mohtadi M, Prange M, Oppo DW, De Pol-Holz R, Merkel U, Zhang X, Steinke S, Lückge A (2014) North Atlantic forcing of tropical Indian Ocean climate. Nature 509:76-80

Morrissey A, Scholz CA (2014) Paleohydrology of Lake Turkana and its influence on the Nile River system. Palaeogeogr Palaeoclimatol Palaeoecol 403:88-100

Nakamura A, Yokoyama Y, Maemoku H, Yagi H, Okamura M, Matsuoka H, Miyake N, Osada T, Adhikari DP, Dangol V, Ikehara M, Miyairi Y, Matsuzaki H (2016) Weak monsoon event at $4.2 \mathrm{ka}$ recorded in sediment from Lake Rara. Himalayas Quat Int 397:349-359

Nicholson SE (1982) Pleistocene and Holocene climates in Africa. Nature 296:779

O'Leary MH (1988) Carbon isotopes in photosynthesis. Bioscience 38:328-336

Osmaston HA, Mitchell WA, Osmaston JAN (2005) Quaternary glaciation of the Bale Mountains, Ethiopia. J Quat Sci 20:593-606

Ossendorf G, Groos A, Bromm T, Girma Tekelemariam M, Glaser B, Lesur J, Schmidt J, Akçar N, Bekele T, Beldados A, Demissew S, Hadush Kahsay T, Nash P, B, Nauss T, Negash A, Nemomissa S, Veit H, Vogelsang R, Zerihun W, Miehe G, (2019) Middle Stone Age foragers resided in high elevations of the glaciated Bale Mountains. Ethiopia. Science 365(80):583-587

Panizzo VN, Mackay AW, Ssemmanda I, Taylor R, Rose N, Leng MJ (2008) A 140-year record of recent changes in aquatic productivity in a remote, tropical alpine lake in the Rwenzori Mountain National Park, Uganda. J Paleolimnol 40:325-338

Raymond PA, Bauer JE (2001) Riverine export of aged terrestrial organic matter to the North Atlantic Ocean. Nature 409:497-500

Reimer PJ, Bard E, Bayliss A, Beck JW, Blackwell PG, Ramsey $\mathrm{CB}$, Buck CE, Cheng H, Edwards RL, Friedrich M, Grootes PM, Guilderson TP, Haflidason H, Hajdas I, Hatté C, Heaton TJ, Hoffmann DL, Hogg AG, Hughen KA, Kaiser KF, Kromer B, Manning SW, Niu M, Reimer RW, Richards DA, Scott EM, Southon JR, Staff RA, Turney CSM, van der Plicht J (2013) IntCal13 and Marine13 Radiocarbon Age Calibration Curves 0-50,000 Years cal BP. Radiocarbon 55:1869-1887

Roberts N, Taieb M, Barker P, Damnati B, Icole M, Williamson D (1993) Timing of the younger dryas event in East Africa from lake-level changes. Nature 366:146-148

Rose NL (2015) Spheroidal carbonaceous fly ash particles provide a globally synchronous stratigraphic marker for the anthropocene. Environ Sci Technol 49:4155-4162

Rose NL (2008) Quality control in the analysis of lake sediments for spheroidal carbonaceous particles. Limnol Oceanogr Methods 6:172-179

Rose NL (1994) A note on further refinements to a procedure for the extraction of carbonaceous fly-ash particles from sediments. J Paleolimnol 11:201-204

Sagnotti L, Caricchi C (2018) StratFit: an excel workbook for correlation of multiple stratigraphic trends

Salazar G, Zhang Y, Agrios K, Szidat S (2015) Development of a method for fast and automatic radiocarbon measurement of aerosol samples by online coupling of an elemental analyzer with a MICADAS AMS. Nucl Instruments Methods Phys Res Sect B Beam Interact with Mater Atoms 111:

Sirocko F, Dietrich S, Veres D, Grootes PM, Schaber-Mohr K, Seelos K, Nadeau M-J, Kromer B, Rothacker L, Röhner M, Krbetschek M, Appleby P, Hambach U, Rolf C, Sudo M, Grim S (2013) Multi-proxy dating of Holocene maar lakes and Pleistocene dry maar sediments in the Eifel, Germany. Quat Sci Rev 62:56-76 
Stager JC, Mayewski PA, Meeker LD (2002) Cooling cycles, Heinrich event 1, and the desiccation of Lake Victoria. Palaeogeogr Palaeoclimatol Palaeoecol 183:169-178

Stoof-Leichsenring KR, Junginger A, Olaka LA, Tiedemann R, Trauth MH (2011) Environmental variability in Lake Naivasha, Kenya, over the last two centuries. J Paleolimnol 45:353-367

Street-Perrott FA, Perrott RA (1990) Abrupt climate fluctuations in the tropics: the influence of Atlantic Ocean circulation. Nature 343:607-612

Szidat S, Salazar A, G, Vogel E, Battaglia M, Wacker L, Synal H-A, Türler A, (2014) 14C analysis and sample preparation at the new bern laboratory for the analysis of radiocarbon with AMS (LARA). Radiocarbon 56:561-566

Talbot MR, Filippi ML, Jensen NB, Tiercelin J-J (2007) An abrupt change in the African monsoon at the end of the Younger Dryas. Geochemistry, Geophys Geosystems 8:n/ a-n/a

Talbot MR, Lærdal T (2000) The Late Pleistocene - Holocene palaeolimnology of Lake Victoria, East Africa, based upon elemental and isotopic analyses of sedimentary organic matter. J Paleolimnol 23:141-164

Tarasov PE, Müller S, Zech M, Andreeva D, Diekmann B, Leipe C (2013) Last glacial vegetation reconstructions in the extreme-continental eastern Asia: Potentials of pollen and n-alkane biomarker analyses. Quat Int s 290-291:253-263

Thompson LG, Mosley-Thompson E, Davis ME, Henderson KA, Brecher HH, Zagorodnov VS, Mashiotta TA, Lin P-N, Mikhalenko VN, Hardy DR, Beer J (2002) Kilimanjaro ice core records: evidence of holocene climate change in Tropical Africa. Science 298(80):589-593

Tiercelin JJ, Gibert E, Umer M, Bonnefille R, Disnar JR, Lézine AM, Hureau-Mazaudier D, Travi Y, Keravis D, Lamb HF (2008) High-resolution sedimentary record of the last deglaciation from a high-altitude lake in Ethiopia. Quat Sci Rev 27:449-467

Tierney JE, Russell JM, Sinninghe Damsté JS, Huang Y, Verschuren D (2011) Late Quaternary behavior of the East African monsoon and the importance of the Congo Air Boundary. Quat Sci Rev 30:798-807

Tomlinson E, Thordarson T, Müller W, Thirlwall M, Menzies M (2010) Microanalysis of tephra by LA-ICP-MS - Strategies, advantages and limitations assessed using the Thorsmörk ignimbrite (Southern Iceland). Chem Geol 279:73-89

Uhlig S, Uhlig K (1991) Studies on the Altitudinal Zonation of Forests and Alpine Plants in the Central Bale Mountains, Ethiopia
Uhlig SK (1988) Mountain Forests and the Upper Tree Limit on the Southeastern Plateau of Ethiopia. Mt Res Dev 8:227-234

Umer M, Lamb HF, Bonnefille R, Lézine AM, Tiercelin JJ, Gibert E, Cazet JP, Watrin J (2007) Late Pleistocene and Holocene vegetation history of the Bale Mountains, Ethiopia. Quat Sci Rev 26:2229-2246

Viehberg FA, Just J, Dean JR, Wagner B, Franz SO, Klasen N, Kleinen T, Ludwig P, Asrat A, Lamb HF, Leng MJ, Rethemeyer J, Milodowski AE, Claussen M, Schäbitz F (2018) Environmental change during MIS4 and MIS 3 opened corridors in the Horn of Africa for Homo sapiens expansion. Quat Sci Rev 202:139-153

Wagner B, Wennrich V, Viehberg F, Junginger A, Kolvenbach A, Rethemeyer J, Schaebitz F, Schmiedl G (2018) Holocene rainfall runoff in the central Ethiopian highlands and evolution of the River Nile drainage system as revealed from a sediment record from Lake Dendi. Glob Planet Change 163:29-43

Werdecker J (1962) Eine Durchquerung des Goba-Massivs in Südäthiopien. Hermann vo:132-144

Williams FM (2016) The Southeastern Highlands and the Ogaden BT - Understanding Ethiopia: Geology and Scenery. In: International S (ed) Williams FM. Publishing, Cham, pp 153-170

Woldu Z, Feoli E, Nigatu L (1989) Partitioning an elevation gradient of vegetation from southeastern Ethiopia by probabilistic methods. Plant Ecol 81:189-198

Zech M, Kreutzer S, Zech R, Goslar T, Meszner S, McIntyre C, Häggi C, Eglinton T, Faust D, Fuchs M et al (2017) Comparative ${ }^{14} \mathrm{C}$ and OSL dating of loess-paleosol sequences to evaluate post-depositional contamination of $n$-alkane biomarkers. Quat Res 87:180-189

Zech M, Glaser B (2009) Compound-specific $\delta^{18} \mathrm{O}$ analyses of neutral sugars in soils using gas chromatography-pyrolysis-isotope ratio mass spectrometry: problems, possible solutions and a first application. Rapid Commun Mass Spectrom 23:3522-3532

Zech M, Zech R, Glaser B (2007) A 240,000-year stable carbon and nitrogen isotope record from a loess-like palaeosol sequence in the Tumara Valley, Northeast Siberia. Chem Geol 242:307-318

Publisher's Note Springer Nature remains neutral with regard to jurisdictional claims in published maps and institutional affiliations. 